\title{
Development of prokaryotic cell-free systems for synthetic biology
}

Abel C. Chiao ${ }^{12}$, Richard M. Murray ${ }^{1}$, Zachary Z. Sun ${ }^{12^{*}}$

${ }^{1}$ Division of Biology and Biological Engineering, California Institute of Technology, Pasadena, CA, USA

${ }^{2}$ Synvitrobio Inc., San Francisco, CA, USA

${ }^{*}$ Correspondence to: Zachary Z. Sun, zsun@post.harvard.edu

Primary Keywords Synthetic biology, industrial biotechnology

Secondary Keywords Cell-free expression systems, biosynthesis, protein expression

NOTE: This is a technical report for future inclusion in work pending submission, review, and publication. Therefore, this work has not been peer-reviewed and is presented asis.

\section{ABSTRACT}

Prokaryotic cell-free systems are currently heavily used for the production of protein that can be otherwise challenging to produce in cells. However, historically cellfree systems were used to explore natural phenomena before the advent of genetic modification and transformation technology. Recently, synthetic biology has seen a resurgence of this historical use of cell-free systems as a prototyping tool of synthetic and natural genetic circuits. For these cell-free systems to be effective prototyping tools, an understanding of cell-free system mechanics must be established that is not purely protein-expression driven. Here we discuss the development of E. coli-based cell-free systems, with an emphasis on documenting published extract and energy preparation methods into a uniform format. We also discuss additional considerations when applying cell-free systems to synthetic biology. 


\section{INTRODUCTION}

Cell-free systems have historically been a fundamental tool for biological research. This was partially a necessity, as transformation technologies to introduce DNA into E. coli (Mandel \& Higa, 1970) and modern recombinant DNA technology (Smith \& Welcox, 1970) were not available until 1970. As a result, many scientific phenomena were limited to probing in crude lysates. The most-well known is Nirenberg's use of a cell-free system to decipher the genetic code for the Nobel Prize in Medicine in 1968 (Nirenberg \& Matthaei, 1961).

When recombinant DNA technology became mainstream and working in cellular hosts the norm, cell-free systems were relegated to the production of hard-to-produce or high-value proteins such as antibodies (Ryabova, Desplancqh, \& Spirin, 1997; Yin et al., 2012) or cytotoxic agents (Martemyanov, Shirokov, Kurnasov, Gudkov, \& Spirin, 2001; Salehi et al., 2016). Significant field focus has been on producing large amounts of proteins, either by engineering of the cell-free system itself (Kigawa, Yabuki, Yoshida, Tsutsui, \& Ito, 1999) or through assisted methods of production (Spirin, Baranov, Ryabova, \& Ovodov, 1988a). These methods all utilize the ability of cell-free systems to efficiently produce protein without interference from cellular growth and metabolism. In addition, many systems are driven by T7 RNA polymerase expression (Krieg \& Melton, 1987 ) to encourage as much protein production as possible. Completely "synthetic" cellfree systems from purified components (Shimizu et al., 2001) have also been developed for hard-to-produce proteins.

There has been a recent resurgence of using cell-free systems as a fundamental tool. An overview contrasting this approach to utilizing systems for expression is given in Figure 1. The goal is similar to original applications probing biological phenomena, but motivated by modern-day synthetic biology tools of DNA sequencing, synthesis, and assembly. The first implementation of this was in 2003 , with genetic circuits in cell-free (Noireaux, Bar-Ziv, \& Libchaber, 2003), followed by the high expression of native sigma70 promoters (Shin \& Noireaux, 2010) and the implementation of a panel of native circuits (Shin \& Noireaux, 2012). By uncoupling protein expression activity from cellgrowth requirements and opening the system to external manipulation and perturbation, 
cell-free is increasingly being used as a "prototyping environment," or an environment for testing hypotheses before final implementation (in a cell, or a cell-free environment) (Niederholtmeyer, Sun, Hori, \& Yeung, 2015; Takahashi et al., 2014). The emphasis in this application is less on protein production and more on the data collected from the cell-free system itself.

In this review, we focus on the development and application of cell-free systems in synthetic biology. This diverges from, but builds off of previous in-depth reviews that take a broad-focus of cell-free systems as an expression platform (Carlson, Gan, Hodgman, \& Jewett, 2012; Hodgman \& Jewett, 2012; James R Swartz, 2012; Jim Swartz, 2006) or focus on engineering in cell-free (Takahashi et al., 2015). In doing so, we will explore the extensive prior research in cell-free system production and energy regeneration, as well as methods of executing cell-free reactions.

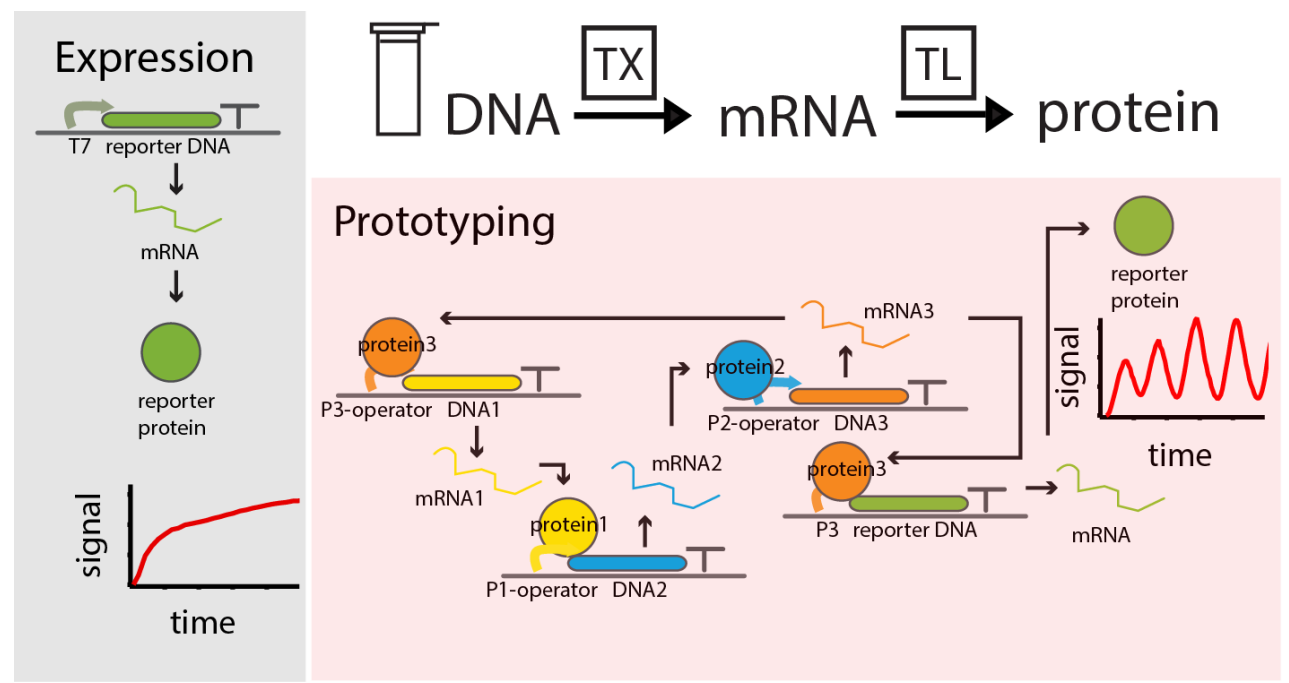

Figure 1.

Overview of cellfree expression process. Execution is split into expression (left) and prototyping (right). On the right, the prototyping of a 3node oscillator is represented. 


\section{E. coli EXTRACT PREPARATION METHODS}

Since the earliest method for the cell-free synthesis of proteins was published by Nirenberg in 1961 (Nirenberg \& Matthaei, 1961), numerous modified and improved protocols have been created. A detailed system published by Zubay in 1973 became what is considered to be the standard "S30" protocol upon which subsequent protocols were based (Spirin \& Swartz, 2008; Zubay, 1973).

Generally, these protocols share a common schematic with the following features: a specific strain of $E$. coli upon which the extract is based, a strategy for cell culture, an elected method for cellular lysis, a centrifugation step to clarify the lysate, a heat incubation (run-off), dialysis, and post-dialysis clarification. Although this remains a fairly faithful general representation of the extract preparation process, none of these parameters were left unexplored in later iterations of the cell-free system and accordingly, current protocols do deviate from this paradigm. We parse extract production into the component pieces specified and evaluate the developments targeting each step (Figure 2).

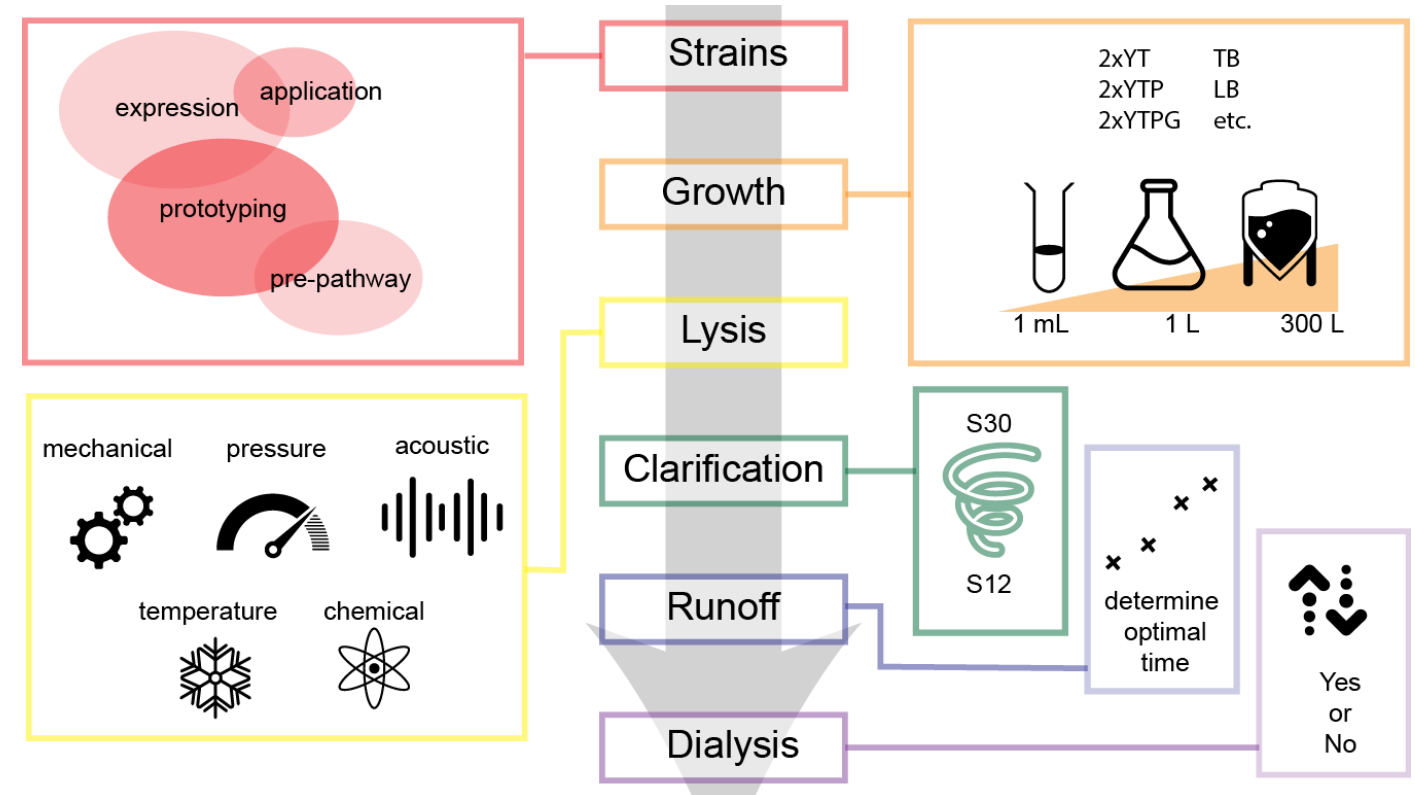

Figure 2. Flow-chart schematic for extract preparation. Preparation is divided into: strain (red), growth conditions (orange), lysis (yellow), clarification (green), runoff determination (blue), and dialysis (purple). 


\section{Strain selection}

Selection of model organism is critical as different $E$. coli strains offer a variety of different advantages over one another. Strains are differentiated by their engineered traits, some of which are very conducive to the controlled expression of protein. Choice of organism presents the first unit of modularity in the construction of cell-free systems. Engineered properties critical to the development of new applications can be directly conferred from engineered strains to their extracts. E. coli extracts have been successfully produced from a number of different cell strains. We divide strain selection into 4 overlapping areas: protein production-optimized strains, application-specific strains, generic strains, and pre-programmed pathway strains. Common genes overexpressed and under-expressed are in Table 1, and common strains are in Table 2.

\section{Protein production optimized strains}

Increasing protein production yield has been one of the main focuses of cell-free optimization. Many of the strain modification findings in this area were pioneered by Swartz and colleagues from 2004 onwards. Earlier efforts on engineering cell-free systems focused on utilizing physical systems (D. M. Kim \& Choi, 1996; Spirin, Baranov, Ryabova, Ovodov, \& Alakhov, 1988b)) and engineering energy regeneration (Kigawa et al., 1999; Ryabova, Vinokurov, Shekhovtsova, Alakhov, \& Spirin, 1995). However, in 2004 a seminal paper from Swartz et al. described deletions in genes encoding for amino acid degradation enzymes, thereby stabilizing amino acid supply and protein production (Michel-Reydellet, Calhoun, \& Swartz, 2004). The paper identified four limiting amino acids: arginine, serine, tryptophan, and cysteine. Arginine was stabilized by removing speA, a gene encoding for a arginine decarboxylase, thereby inhibiting the conversion of arginine to putrescine. Serine was stabilized by removing serine deaminases $s d a A$ and $s d a B$, inhibiting the conversion of serine to pyruvate. Tryptophan was stabilized by removing tnaA. There was an additional attempt to stabilize cysteine, but deletions in thaA and $y f h Q$ failed to achieve desired results. A follow-up paper identified a deletion in gshA, a glutamate-cysteine ligase, as the 
cysteine degradation culprit (Calhoun \& Swartz, 2006). The resulting strain was named KC6 (Calhoun \& Swartz, 2005a; Michel-Reydellet et al., 2004).

To stabilize templates off of which DNA can be translated, the lambda-phage cluster has also been inserted into strains made into cell-free lysates (Michel-Reydellet, Woodrow, \& Swartz, 2005), creating the NMR5 strain. The insertion of lambda-phase cluster represented one of the first strain-engineering attempts at stabilizing linear DNA. Although the cluster was identified as exo and beta in (Michel-Reydellet et al., 2005), earlier efforts revealed gam, when added in purified form, to be the main RecBCD inhibitor and linear DNA stabilizer (Sitaraman et al., 2004).

Separately, work from the Kim (HJ) lab in 2005 identified strains with the overexpression of molecular chaperones capable of reducing aggregation and improve solubility of eukaryotic proteins such as human erythropoietin (Kang et al., 2005). The work inserted plasmids to overexpress chaperone and heat-shock genes groEL/ES, $d n a K / J$ and $g r p E$, or $d s b C$. Interestingly, the Kim group also explored the creation of extracts from the Origami strain (Novagen) that encourages disulfide bond formation. The roles of proteins $\operatorname{trx} B, g o r$, and $d s b C$ would for later formally explored in the context of disulfide bond formation in (Knapp, Goerke, \& Swartz, 2007).

With the success in engineering amino acid stability, high-throughput approaches for determining positive and negative factors to cell-free expression was explored. In a first attempt, Woodrow et al. expressed 55 genes from $E$. coli off of linear DNA templates in NMR5, and demonstrated gene expression (Kim A Woodrow, Isoken $\mathrm{O}$ Airen, \& Swartz, 2006). This work was followed by an expression of 49 genes affecting transcription, folding, energy, and cell-division, coupled to a selective degradation of linear templates with Dpnll (on methylation pattern) and a subsequent analysis of cellfree yields (Woodrow \& Swartz, 2007). In a final iteration, Airen (in unpublished but peer-reviewed thesis work) expressed 3,789 E. coli open reading frames, identifying 79 positive effectors and 60 negative effectors (Airen, 2011). Using this information on negative effectors, 4 mutant strains were made that, when combined with (1) supplementation with positive effectors, (2) stabilization of $\mathrm{pH}$, (3) substrate replenishment, and (4) mRNA stabilization were able to increase expression 3-4-fold. 
While strains with 4 negative effectors removed, $p n p$, $r n b$, raiA, and mazG, did not result in significant increased expression, supplementation in $i b p A$, ibpB, if-1, if-2, if-3, and eftu demonstrated increased yields (Airen, 2011; Woodrow \& Swartz, 2007). Negative effectors $r n a, r n b, c s d A, \operatorname{maz} F$, and endA have also been removed from newer MAGErecoded $(\mathrm{H}$. H. Wang et al., 2009) strains, resulting in increased fluorescent protein yield. rna and $r n b$ code for RNAses, csdA for a cold-shock protein that degrades mRNA, mazF for a RNA-degrading toxin, and endA for a dsDNA endonuclease (Hong et al., 2015).

\section{Application specific strains}

Strain modifications have also been explored to enable the expression of proteins with disulfide bonds. Disulfide bonds are a common feature of mammalian proteins, but are difficult to implement in cell-free due to rapid reduction in vitro (Jim Swartz, 2006). While iodoacetamide treatment can inactive thiols responsible for reducing disulfide bonds (Yin \& Swartz, 2004), the treatment globally targets -SH groups and can result in non-specific inactivation of critical enzymes (such as DsbC and G-3PDH) (Knapp et al., 2007). A workaround was through the creation of a deletion mutant of trxB (thioredoxin reductase) and gor (glutathione reductase) and supplementation with DsbC. Critically, $\operatorname{trx} B$ is tagged with a hemagglutinin tag to allow for it to be present during cell growth but removed after cell-free processing, as a double trxB gor knockout causes ahpC to mutate to a potent disulfide reductase (Knapp et al., 2007). It is noted that this genotype closely represents the Origami strain (Novagen) that contains knockouts of trxB and gor with suppressor mutations in $a h p C$, and was demonstrated successfully for cell-free production two years prior (Kang et al., 2005). The resulting strain (KGK10) or findings from engineering the strain form the basis for current production efforts of disulfide bond proteins. Commercially, Sutro Biopharma utilizes variants of the strain for producing cytokine rhGM-CSF at 200L scale (Zawada, Yin, Steiner, \& Yang, 2011) and producing antibody fragment light and heavy chains (Yin et al., 2012). 


\section{Generic strains}

While strains can be specifically engineered for protein production or for specific applications, there is also a focus on using "generic" strains for cell-free prototyping. Reasons for using generic strains rather than specialized strains include: (1) Lack of need of high protein expression, and (2) the desire to maintain prototyping fidelity between in vitro and in vivo. Generic strains such as K19, first introduced in 1966 (Gesteland, 1966), have been commonly used (Kigawa et al., 1999; D.-M. Kim, Kigawa, Choi, \& Yokoyama, 1996), as well as MRE-600 (Spirin et al., 1988a), BL21-derivatives (CP strains (Kigawa, Yabuki, Matsuda, Matsuda, Nakajima, Tanaka, \& Yokoyama, 2004a), Rosetta strains ((de los Santos, Meyerowitz, Mayo, \& Murray, 2015; Shin \& Noireaux, 2012; Sitaraman et al., 2004; Sun et al., 2013; Sun, Yeung, Hayes, Noireaux, \& Murray, 2014; Takahashi et al., 2014)), DE3 strains ((Karim \& Jewett, 2016; Kwon \& Jewett, 2015; Kwon et al., 2013), Origami strains ((Kang et al., 2005)), and K12 MG1655 (Kwon \& Jewett, 2015). These generic strains can be chosen for favorable properties of growth; for example, the Rosetta derivatives provide rare tRNAs, DE3derivatives provide T7 RNA Polymerase, BL21-derivatives are optimized for protein production, and Origami derivatives optimize for disulfide bond formation with $t x r B$ and gor deletions. However, selection does not need to be limited to widely recognized substrains. For example, cells with lacl, araC, and tetR knockouts such as JS006 (Stricker et al., 2008) have been made into extracts to build oscillators that require exogenous lacl (Niederholtmeyer et al., 2015). In the reverse case, ExpressIQ (laclQ) has been used to shut-down operons that are lacl sensitive (Sun, Kim, Singhal, \& Murray, 2015). Commercially, cells optimized for 1,4-BDO production were used by Genomatica as the starting strain for lysis, to test hypotheses of expression efficiency (Fischer, 2016; Schilling, 2015). If using cell-free as a prototyping platform, where the data collected from cell-free systems is critical, the selection of strain is driven by the final in vivo implementation.

\section{Pre-programmed pathway strains}


Recently, strains with complete pathways already present have also been made into cell-free systems for the purposes of driving production of a specific product. This is distinct from directed cell-free synthesis of products by the combination of separate cellfree lysates, each with a single enzyme to drive catalysis, as exemplified by Zhang (YHP) and colleagues ((Rollin et al., 2015; Y. Wang, Huang, Sathitsuksanoh, Zhu, \& Zhang, 2011).

Greenlight Biosciences has pioneered a unique method to produce cell-free systems pre-programmed with metabolic pathways of the product of interest, where energy flux is solely directed towards producing the product (and not towards cellular growth). This is achieved by compartmentalizing the cell into a cytoplasm and a periplasm, where the cytoplasm contains the pathway of interest without a key enzyme and the periplasm contains the key enzyme and proteases against tagged proteins that are essential for cellular growth and function (but divert metabolic flux in vitro) (James $R$ Swartz, 2012). Upon lysis, both compartments are brought together. The protease can then degrade the tagged growth-related proteins, while the key enzyme can run the pathway. This process can be achieved by engineering the strain to have protein degradation tags on growth-related proteins and periplasm-export tags on key enzymes. 
Table 1. Genes commonly over-expressed or under-expressed in engineered cellfree strains. Citations indicate where more information about the gene in the context of cell-free can be found.

\begin{tabular}{|c|c|c|}
\hline Gene & Description & Citation \\
\hline ackA+ & acetate kinase, added to increase yield & (Airen, 2011) \\
\hline csdA- & $\begin{array}{l}\text { cold shock degradosome protein, removed to prevent mRNA } \\
\text { decay during preparation }\end{array}$ & (Hong et al., 2015) \\
\hline dnaJ+ & chaperone protein, added to assist folding with dnaK, grpE & (Kang et al., 2005) \\
\hline dnaK+ & chaperone protein, added to assist folding with dnaJ, grpE & (Kang et al., 2005) \\
\hline dsbC+ & disulfide isomerase, added for disulfide bond formation & $\begin{array}{l}\text { (J. Yang, Kanter, Voloshin, } \\
\text { Levy, \& Swartz, 2004; Yin \& } \\
\text { Swartz, 2004) }\end{array}$ \\
\hline ef-tu+ & $\begin{array}{l}\text { translation factor, added to increase yields (most abundant } \\
\text { protein in cell, potentially rate-limiting) }\end{array}$ & $\begin{array}{l}\text { (Airen, 2011; Woodrow \& } \\
\text { Swartz, 2007) }\end{array}$ \\
\hline endA- & endonuclease, removed for plasmid stability & (Michel-Reydellet et al., 2004) \\
\hline gamS+ & lambda gam, added to protect linear DNA & $\begin{array}{l}\text { (Michel-Reydellet et al., 2005; } \\
\text { Sitaraman et al., 2004; Sun et } \\
\text { al., 2014) }\end{array}$ \\
\hline gorB- & $\begin{array}{l}\text { glutathione reductase, removed to prevent disulfide bond } \\
\text { persistence }\end{array}$ & $\begin{array}{l}\text { (Kang et al., 2005; Knapp et al., } \\
2007 \text { ) }\end{array}$ \\
\hline groEJ+ & chaperone protein, added to assist folding with groEL+ & (Kang et al., 2005) \\
\hline groEL+ & chaperone protein, added to assist folding with groEJ+ & (Kang et al., 2005) \\
\hline grpE+ & heat shock protein, added to assist folding with dnaJ, dnaK & (Kang et al., 2005) \\
\hline gshA- & glutamate-cysteine ligase, removed to stabilize cysteine & (Calhoun \& Swartz, 2006) \\
\hline hchAt & chaperone protein, added to increase solubility and yield & (Airen, 2011) \\
\hline ibpA+ & $\begin{array}{l}\text { small heat shock protein (chaperone), added to increase } \\
\text { solubility and yield }\end{array}$ & (Airen, 2011) \\
\hline ibpB+ & $\begin{array}{l}\text { small heat shock protein (chaperone), added to increase } \\
\text { solubility and yield }\end{array}$ & (Airen, 2011) \\
\hline If-1+ & initiation factor 1 , added to increase yield & (Airen, 2011) \\
\hline If-2+ & initiation factor 2 , added to increase yield & (Airen, 2011) \\
\hline If-3+ & initiation factor 3 , added to increase yield & $\begin{array}{l}\text { (Airen, 2011; Kim A Woodrow et } \\
\text { al., 2006; Woodrow \& Swartz, } \\
\text { 2007) US } 20130316397\end{array}$ \\
\hline lacl- & $\begin{array}{l}\text { lacl repressor, removed to prevent interference with lacl- } \\
\text { expressing circuits }\end{array}$ & (Niederholtmeyer et al., 2015) \\
\hline mazF- & $\begin{array}{l}\text { mazF toxin, removed to prevent mRNA degradation at 'ACA' } \\
\text { sites }\end{array}$ & (Hong et al., 2015) \\
\hline met+ & P1 selection marker, engineering scar & (Michel-Reydellet et al., 2004) \\
\hline recD- & recD, removed to protect linear DNA (ineffective) & (Michel-Reydellet et al., 2005) \\
\hline rna- & RNAse $A$, removed for RNA stability & $\begin{array}{l}\text { (Gesteland, 1966; D.-M. Kim et } \\
\text { al., 1996) }\end{array}$ \\
\hline rnb- & RNAse II, removed for RNA stability & $\begin{array}{l}\text { (Hong et al., 2015; Woodrow \& } \\
\text { Swartz, 2007) }\end{array}$ \\
\hline rpfA- & release factor 1 , removed to encourage nsAA incorporation & (Hong et al., 2014) \\
\hline sdaA- & serine deaminase, removed to stabilize serine & (Michel-Reydellet et al., 2004) \\
\hline sdaB- & serine deaminase, removed to stabilize serine & (Michel-Reydellet et al., 2004) \\
\hline speA- & arginine decarboxylase, removed to stabilize arginine & (Michel-Reydellet et al., 2004) \\
\hline tnaA- & tryptophanase, removed to stabilize tryptophan & (Michel-Reydellet et al., 2004) \\
\hline tonA- & outer membrane protein, engineering scar & (Michel-Reydellet et al., 2004) \\
\hline trxB- & thioredoxin reductase, removed post-growth with HA tag to & (Kang et al., 2005; Knapp et al., \\
\hline
\end{tabular}


Table 2. Commonly used strains, with genotypes. Citations indicate originally developed locations and/or application

\begin{tabular}{|c|c|c|}
\hline Strain & Genotype & Citation \\
\hline $\begin{array}{l}\text { BL21- } \\
\text { Rosetta2 }\end{array}$ & $\begin{array}{l}\mathrm{F}^{-} \text {ompT hsd } S_{\mathrm{B}}\left(\mathrm{r}_{\mathrm{B}}^{-} \mathrm{m}_{\mathrm{B}}^{-}\right) \text {gal dcm (DE3) pRARE2 } \\
\text { (Novagen) }\end{array}$ & $\begin{array}{l}\text { (Shin \& Noireaux, 2010; 2012; } \\
\text { Sun et al., 2014) }\end{array}$ \\
\hline JS006 & MG1655 araC- lacl- & $\begin{array}{l}\text { (Niederholtmeyer et al., 2015; } \\
\text { Stricker et al., 2008) }\end{array}$ \\
\hline K12-A19 & rna- gdhA2 relA1 spoT metB1 & $\begin{array}{l}\text { (Gesteland, 1966; D.-M. Kim et } \\
\text { al., 1996) }\end{array}$ \\
\hline KC1 & A19 speA- tnaA- tonA- endA- sdaA- sdaB- met+ & (Michel-Reydellet et al., 2004) \\
\hline KC6 & KC1 gshA- & (Calhoun \& Swartz, 2005a) \\
\hline KG6-der. & $\begin{array}{l}\text { KC6 rnb- ackA+ ef-tu+ hchA+ibpA+ibpB+if-1+ if- } 2+ \\
\text { if-3+ }\end{array}$ & US20130316397 \\
\hline KGK10 & KC6 gorB- trxB-HA & $\begin{array}{l}\text { (Knapp et al., 2007; Knapp \& } \\
\text { Swartz, 2007; Yin et al., 2012; } \\
\text { Zawada et al., 2011) }\end{array}$ \\
\hline NMR1 & A19 endA- met+ & (Michel-Reydellet et al., 2004) \\
\hline NMR2 & A19 speA- tnaA- tonA- endA- met+ & (Michel-Reydellet et al., 2004) \\
\hline NMR4 & A19 recD- endA- met+ & (Michel-Reydellet et al., 2005) \\
\hline NMR5 & A19 lambda-phage<>recBCD met+ & (Michel-Reydellet et al., 2005) \\
\hline S30BL/Dna & BL21(DE3) dnaK/J+ grpE+ & (Kang et al., 2005) \\
\hline S30BL/DsbC & BL21(DE3) dsbC+ & (Kang et al., 2005) \\
\hline S30BL/GroE & BL21(DE3) groEL/ES+ & (Kang et al., 2005) \\
\hline S30OB & $\begin{array}{l}\mathrm{F}^{-} \text {omp Thsd } \mathrm{S}_{\mathrm{B}}\left(\mathrm{r}_{\mathrm{B}} \mathrm{m}_{\mathrm{B}}^{-}\right) \text {gal dcm lacY1 } \\
\text { ahpC (DE3) gor522:: Tn10 trxB (Novagen) }\end{array}$ & (Kang et al., 2005) \\
\hline S300B/Dna & S30OB dnaK/J+ grpE+ & (Kang et al., 2005) \\
\hline S30OB/DsbC & S30OB dsbC+ & (Kang et al., 2005) \\
\hline S30OB/GroE & S30OB groEL/ES+ & (Kang et al., 2005) \\
\hline
\end{tabular}




\section{Growth conditions}

\section{Growth volume}

Historically, fermenters have been used to produce cell biomass. The original protocols utilized fermenters of up to $10 \mathrm{~L}$ in size to grow cells (Zubay, 1973). Building off of this, Swartz et al. demonstrated a $10 \mathrm{~L}$ scale $(20 \mathrm{~g} / \mathrm{L}$ wet pellet cell mass), which produced similar cell-free protein yield as shake-flask growth (Zawada \& Swartz, 2005), but with the advantage of denser OD collection. The same protocol is cited by Sutro Biopharma in (Zawada et al., 2011), but utilizing a 200 L bioreactor also customretrofitted with baffles. In both cases, feed rates of glucose are controlled to prevent acetate accumulation. Fermenters can be used to scale up biomass production, but suffer from increased labor and monitoring needed to collect data.

In lieu, growth can be conducted on a shake-flask scale $(1 \mathrm{~L}$ of cell culture in a 2.8 $L-4 L$ Erlenmeyer flask), which yields about 1-2 $\mathrm{mL}$ of crude extract per $\mathrm{L}$ (Sun et al., 2013). Shake-flasks allow for quick production of biomass without fermenter maintenance. Protocols are focused on maintaining fast growth and aeration before capture at culture mid-log phase, and thus typically use baffled flasks. Examples of protocols using shake-flasks can be found at (Kigawa, Yabuki, Matsuda, Matsuda, Nakajima, Tanaka, \& Yokoyama, 2004b; Sun et al., 2013; W. C. Yang, Patel, Wong, \& Swartz, 2012).

For smaller volumes, a recent protocol by Kwon and Jewett demonstrates the first rapid production of cell-free at the $10 \mathrm{~mL}$ culture tube, allowing for the rapid exploration of $\sim 100$ strains per day using basic, readily available equipment (sonicator, small shaker, tabletop centrifuge) (Kwon \& Jewett, 2015). Expression levels from the 10 $\mathrm{mL}$ scale produce comparable protein to the $10 \mathrm{~L}$ scale. By allowing for small-scale but high throughput production, Kwon and Jewett's protocol scales cell-free expression for exploring multiple rapidly-engineered strains or conditions. 


\section{Growth media}

While older protocols utilized $28^{\circ} \mathrm{C}$ growth (Zubay, 1973), the current standard protocol utilizes $37^{\circ} \mathrm{C}$ growth to encourage rapid protein production. This is driven by the knowledge that ribosome concentration correlates directly with growth rate (Bosdriesz, Molenaar, Teusink, \& Bruggeman, 2015). There is evidence that temperature, effecting growth rate, has a direct correlation with extract productivity. In particular, Kigawa and colleagues have found that extracts have a linear productivity from $20^{\circ} \mathrm{C}$ to $37^{\circ} \mathrm{C}$ of growth, where CAT production yield at $20^{\circ} \mathrm{C}$ is $66 \%$ that of $37^{\circ} \mathrm{C}$ (Seki, Matsuda, Yokoyama, \& Kigawa, 2008). Similarly, Nakano's lab identified aminoacid supplemented growth conditions that enabled cell-free growth of $\mathrm{A} 19$ at $42^{\circ} \mathrm{C}$, yielding $40 \%$ more CAT production yield compared to $37^{\circ} \mathrm{C}$ growth (Yamane, Ikeda, Nagasaka, \& Nakano, 2005). However, to date we are not aware of other protocols utilizing $42^{\circ} \mathrm{C}$ growth.

Growth medias vary from extract to extract perpetration, although in general medias used are complex, non-defined mixtures such as LB, 2xYT, etc. (Spirin \& Swartz, 2008). Medias can be supplemented for limiting reagents; for example, asparagine, glutamine, and tryptophan (Yamane et al., 2005) is added to a complex media to encourage faster growth. For specific applications such as fermenter growth, glucose and amino acid concentration can be selectively monitored and fed to prevent acetate accumulation (Zawada \& Swartz, 2005). In addition, in $2000 \mathrm{Kim}$ and Choi identified the addition of phosphate and glucose to a 2xYT media (named 2xYT-PG) to be suppressive of phosphatase activity in the resulting extracts (R. G. Kim \& Choi, 2000). Phosphatase activity was found to consume energy sources PEP and amino acid cysteine. The group's working hypothesis was supplementation of phosphate and glucose would prevent the cell from making its own phosphatases to produce inorganic phosphate. This media forms the basis for most modern cell-free preparations. It is noted that cell-free formulations for prototyping to-date have removed glucose from the media (Caschera \& Noireaux, 2015; Shin \& Noireaux, 2010; Sun et al., 2013) for unknown reasons. 


\section{Lysis methods}

Following culture, a number of options exist for lysing the cells and harvesting. Considerations of note when selecting a lysis method are lysis efficiency, scaling potential, ease of use, and preservation of native cell components. Different lysis techniques have different pros and cons and consequently, different protocols have cell disruption methods tailored to their applications. There has been relatively little innovation in this area; reviews addressing general cell lysis, such as one from 1986, provide good overviews of the different methods (Chisti \& Moo-Young, 1986). We divide our discussion of lysis methods into five categories: mechanical (non-pressure), mechanical (pressure), acoustic, temperature, and chemical.

\section{Mechanical (non-pressure-based) lysis}

Mechanical methods utilize a grinding mechanism of action. These techniques involve the agitation of a suspension of cells in the presence of ceramic/glass beads, the motion of which results in crushing and grinding forces that break apart the cells and efficiently shears DNA (Miller, Bryant, Madsen, \& Ghiorse, 1999). Industrial scale beadmills have been deployed for cellular lysis (Chisti \& Moo-Young, 1986), although the use of "Bead-beater" type desktop devices have been preferred (Thompson \& Chassy, 1981 ) and adopted in cell-free protocols (Kigawa, Yabuki, Matsuda, Matsuda, Nakajima, Tanaka, \& Yokoyama, 2004b; Shrestha, Holland, \& Bundy, 2012; Sun et al., 2013). Beads are easily separated from the lysate by centrifugation/filtering and no expensive equipment is required, greatly reducing the financial barrier of entry into cell-free biology. The protocol also has utility in lysing non-E. coli such as cyanobacteria (Mehta, Evitt, \& Swartz, 2015) and environmental samples from soil (Yeates, Gillings, Davison, Altavilla, \& Veal, 1998). To maintain high protein concentrations necessary for cell-free expression, beads can also be filtered out of solutions post-processing (Sun et al., 2013). As is the case with all mechanical lysis methods, localized sample heating that may denature native proteins is a concern in bead beating methods (Shrestha et al., 2012). This problem is circumvented by limiting lysis to short bursts and by incubating the samples on ice between bursts (Sun et al., 2013). Perhaps the largest drawback to 
this method of lysis is difficulty of scaling up to larger volumes as this method is typically conducted in 1-2 mL tubes. Bead mills present one avenue for scale-up but requires manual loading of extract. The ability to work in small volumes, however, is conducive to producing multiple distinct, small batches. Bead-beating is useful for studies requiring the production of multiple different extract batches, as is the case when conducting protocol modifications.

\section{Mechanical (pressure-based) lysis}

High pressure disruption mechanisms such as impinge homogenizers are among the earliest and most widely utilized methods for lysing cells for the purpose of preparing extracts (Chisti \& Moo-Young, 1986). These work by forcing cell suspensions through a narrow aperture under high pressure. The high-velocity flow of cells either impinges on an opposite high-pressure stream of cells or a rigid valve/nozzle surface. The resulting shear rates and rapid decompression are thought to be critically important in the formation of inverted membrane vesicles in the resultant extracts (Jewett, Calhoun, Voloshin, Wuu, \& Swartz, 2008). Because the enzymes essential to the oxidative phosphorylation pathway must be membrane-associated to function, the possibility of their presence is worth considering when selecting a lysis method. Access to the oxidative phosphorylation pathway potentially increases the metabolic efficiency of extracts, enabling more economical and productive strategies for powering the transcription-translation machinery.

For E. coli extracts, different types of impinge homogenizers are currently in use, ranging from French Press-style homogenization (Caschera \& Noireaux, 2014; D. M. Kim \& Choi, 1996; T. W. Kim et al., 2006) to Avestin ${ }^{\text {TM }}$-type homogenization (Jewett et al., 2008; Liu, Zawada, \& Swartz, 2005; Sitaraman et al., 2004; W. C. Yang et al., 2012). Both types of homogenizers allow for scaling of batches; French-press homogenizers scale up to the size of the press (typically $30 \mathrm{~mL}$ ), while Avestin@-type homogenizers allow for feeding of cell biomass. 


\section{Acoustic lysis}

Sonication, or acoustic lysis, relies on ultrasound energy (15-20kHz) to disrupt cells in solution. The mechanism of lysis is thought to be related to cavitation, a phenomena where microbubbles form at nucleation sites, absorb energy and burst, releasing mechanical shock waves that disrupts the cell wall and can shear DNA (Chisti \& Moo-Young, 1986). There are relatively few examples of sonication being used as a lysis method for $E$. coli cell-free protein synthesis, with an early example failing due to "sample heating and difficulty of management" (Kigawa, Yabuki, Matsuda, Matsuda, Nakajima, Tanaka, \& Yokoyama, 2004b). In 2012, Bundy and colleagues re-attempted sonication as a lysis technique, and were able to successfully demonstrate protein yields comparable to that of high-pressure homogenization, albeit with significant optimization of the sonication burst times and cooling times (Shrestha et al., 2012). In this study, temperature was also not shown to be a damaging factor. This was followed by a study from Kwon and Jewett optimizing energy input to cell-strain and processing volume, which found a surprising strain-dependence (Kwon \& Jewett, 2015). It is anticipated that sonication will be studied further for $E$. coli cell-free systems. Like beadbeating, benefits of sonication include low startup costs and the ability to work with very small volumes.

\section{Temperature based-lysis}

Temperature-based lysis relies on freeze-thaw cycles to disrupt cellular membranes, and is one of the easiest methods of cellular disruption for producing purified proteins (Johnson \& Hecht, 1994; Ron, Kohler, \& Davis, 1966). This lysis can take place with or without enzymatic or chemical assistance such as lysosome. If successful, the method does not require advanced materials (other than liquid nitrogen or -80 C storage). However, freeze-thaw has not been demonstrated successfully for $E$. coli cell-free systems, with no appreciable expression detected despite a 99.6\%-99.9\% lysis efficiency (Shrestha et al., 2012). This is relatively surprising, as freeze-thaw in $20 \%$ glycerol has been demonstrated for Trichoplusia ni (insect) cell-lines (Ezure et al., 2006). 


\section{Chemical lysis}

Chemical lysis relies on the use of enzymes or detergents to remove cell walls, typically used in the context of protein purification. Enzymes such as lysozyme (peptidoglycan layer in E. coli) or benzonase (nuclease to remove DNA and RNA) are commonly utilized in tandem with defined detergents such as Tween-20, Triton-X, or RIPA buffer or commercial mixtures such as BugBuster (Novagen) or CellLytic $X$ (Sigma). To our knowledge, there is no successful production of a coupled cell-free system using chemical lysis, although attempts using lysozyme with freeze-thaw have been unsuccessful (Shrestha et al., 2012). While chemical lysis has been used for anaerobic cell-free activity assays (Kuchenreuther, Shiigi, \& Swartz, 2014), no coupled transcription-translation has been demonstrated.

\section{Clarification}

Following lysis, the resultant solution is typically extremely viscous and difficult to manipulate. For this reason, the lysis step is always followed by a clarification step in which the lysate is spun down in a centrifuge to separate cellular debris from the soluble substrates (active enzymes, small molecules, and co-factors, necessary to drive coupled transcription-translation). Although crude extract can be used with no clarification step, aside from issues arising from viscosity, background expression is increased relative to clarified extracts (T. W. Kim et al., 2006). Traditionally, clarification has consisted of (2x $30 \mathrm{~min}$ ) 30,000 x g spins, a process that comprises a large portion of the processing time (resulting in term S30 extract) (Nirenberg \& Matthaei, 1961). Two washes were later found to be unnecessary, with 1 wash sufficient to obtain equivalent signal (Liu et al., 2005).

In $2006 \mathrm{Kim}$ (DM) and colleagues demonstrated a radical shift in clarification protocols by showing that one $12,000 \times \mathrm{g}$ spin for 10 minutes was successful in maintaining expression (T. W. Kim et al., 2006). Interestingly, cell-free expression from a $12,000 \times \mathrm{g}$ spin followed by no-dialysis was similar to that of the traditional $2 \times 30,000$ x $g$ spins, and crude lysate with no processing showed only marginally less $(20 \%)$ expression. This finding was reproduced independently, demonstrating a $30 \%$ 
increased yield using S12 over S30 (Pedersen, Hellberg, Enberg, \& Karlsson, 2011). S12 preparations also demonstrated increased co-factors relative to S30 preparations (T.-W. Kim, Keum, et al., 2007a). S12 extract demonstrated workable viscosity and decreased background expression, but was strain specific to the Rosetta, BL21, and BL21-Star lines. Subsequently, $12,000 \times \mathrm{g}$ spins have become widely adopted for preparing cell-free systems from compatible strains (Kwon \& Jewett, 2015; Shrestha et al., 2012; Sun et al., 2013).

\section{$\underline{\text { Runoff }}$}

A runoff reaction is typically conducted after clarification of the lysate, presumably to release ribosomes from bound mRNA and degrade leftover, sheared mRNA and DNA from the host strain (Jermutus, Ryabova, \& Plückthun, 1998; Nirenberg, 1963). Before the runoff reaction, solutions are typically clear; afterwards, however, the solutions become cloudy, indicating degradation or modification (Sun et al., 2013). However, there has been little experimental evidence of this hypothesis, and it is a rich area of potential further exploration. Traditionally, the runoff reaction occurs at $37^{\circ} \mathrm{C}$ for 80 minutes, and mixes clarified lysate with a pre-incubation mix of Tris, $\mathrm{Mg}$, ATP, DTT, amino acids, PEP, and pyruvate kinase. However, Swartz and colleagues first reported that the pre-incubation mix was unnecessary to obtain signal (Liu et al., 2005 ), and that a $37^{\circ} \mathrm{C}, 80$-minute incubation of the post-clarified lysate was sufficient. In addition, ribosome release as the reason for the runoff is called into question, with a new hypothesis that the runoff activated activators or degraded inhibitors. Adding to the confusion, in 2015 Kwon and Jewett identified a strain-specific runoff property, with BL21-Star (DE3) strains not requiring runoff to activate protein production and other strains requiring different experimentally-optimized runoff steps (Kwon \& Jewett, 2015). While current protocols for prototyping use a set 80 -minute runoff without pre-incubation (Sun et al., 2013), this area is ripe for future research. 


\section{Dialysis}

After the runoff reaction, lysates are typically re-clarified by centrifugation to remove substrates accumulated during the reaction and dialyzed against a final S30 run buffer at 4 C (Sun et al., 2013). Traditionally, the dialysis step varies in length of time from one cycle of 3 hours (Sun et al., 2013) or 18 hours (Zubay, 1973) to 45 minutes x 4 cycles (Kigawa, Yabuki, Matsuda, Matsuda, Nakajima, Tanaka, \& Yokoyama, 2004b). However, when explored with the runoff Swartz and colleagues found the dialysis step to be unnecessary, with no statistical difference between $0-4$ dialysis cycles (Liu et al., 2005). This was confirmed by Kim (DM) and colleagues, who found dialysis unnecessary in the standard protocol, except when used after a 80 minute runoff step, presumably to remove by-products from the runoff (T. W. Kim et al., 2006). A potential added benefit of removing the dialysis step is the retention of cofactors that would otherwise pass through the $10 \mathrm{kDa}$ membrane used. There currently is a mix of protocols used, with some protocols utilizing dialysis (Garamella, Marshall, Rustad, \& Noireaux, 2016; Sun et al., 2013; W. C. Yang et al., 2012) and others omitting dialysis (Kwon \& Jewett, 2015; Shrestha et al., 2012). The effect of dialysis on extract composition and on prototyping ability is another area ripe for future research. 


\section{E. coli ENERGY REGENERATION}

The development of more efficient methods for energizing cell-free protein synthesis mirrors the maturation of cell-free extracts as a platform for synthetic biology (Figure 3). For decades, the ability to leverage the advantages of cell-free systems in industrial applications was limited by inefficient methods for regenerating ATP necessary for protein synthesis. In addition to being unable to sustain protein synthesis beyond an hour as a result of substrate instability (D. M. Kim \& Choi, 1996; D.-M. Kim \& Swartz, 2000b; R. G. Kim \& Choi, 2000), early energy regeneration systems relied on prohibitively expensive substrates. These issues were gradually addressed by enabling and utilizing increasingly extended pieces of native cell metabolism to more efficiently drive protein synthesis. Much of the exploration in this area was not through building synthetic pathways, but rather through the observation that cell-free lysates innately conserve complex central metabolism, such as pathways for glycolysis and oxidative phosphorylation (Figure 4). For example, for oxidative phosphorylation to work, all enzymes in the TCA cycle and in the electron transport chain must be present and functional (Jewett et al., 2008; Jewett \& Swartz, 2004a).

As a result, the latest cell-free systems feature a thousand-fold improvement in the relative cost of energy substrate demonstrated (Caschera \& Noireaux, 2015) and protein synthesis can be extended to ten hours in simple batch mode (Caschera \& Noireaux, 2014). This is a direct result of being able to exploit $E$. coli sugar metabolism in its entirety. The demonstration of such extensive, intact native machinery and the ability to manipulate its utility signals an important paradigm shift in cell-free systems. Rather than a black-box system used for simple protein production, cell-free extracts have evolved into a complex and valuable prototyping environment.

\section{General requirements}

Although not constrained by energy costs associated with growth and maintenance in whole cells, cell-free extracts are still subject to stringent energy requirements posed by high-volume protein expression. Two molecules of ATP and two GTP are consumed in the formation of each peptide bond. Resource limitation is an 
important consideration in maximizing yields in protein production applications of cellfree reactions but is equally important in successfully implementing multi-step pathways and ensuring fidelity in rapid prototyping functions. Accordingly, a robust energy regeneration system is essential to maximizing extract performance across the board for all cell-free protein synthesis applications. This energy regeneration system must also be capable of avoiding inorganic phosphate accumulation (Spirin \& Swartz, 2008) while maintaining $\mathrm{pH}$ within physiological range. We divide our discussion of energy regeneration in rough chronological order of development: single-step (substrate level) phosphorylation, multi-step pathway phosphorylation and oxidative phosphorylation.

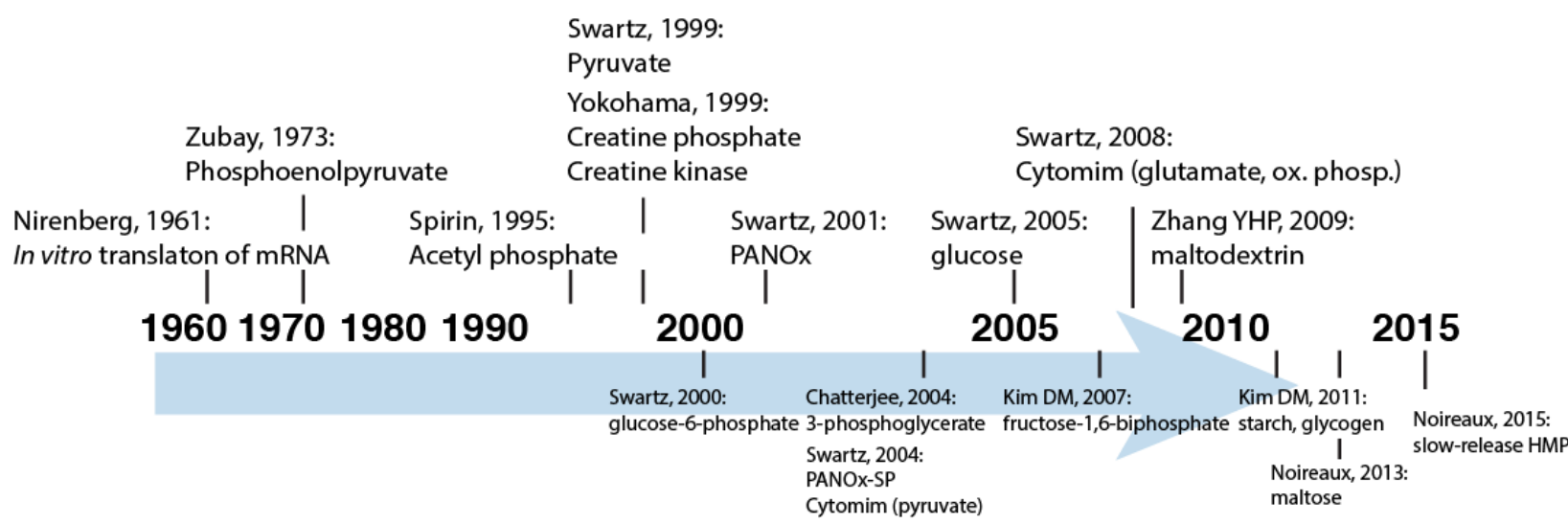

Figure 3. Energy sources to feed cell-free metabolism, arranged by year. Top of figure shows "major" breakthroughs in energy metabolism, while bottom of figure shows other breakthroughs. 


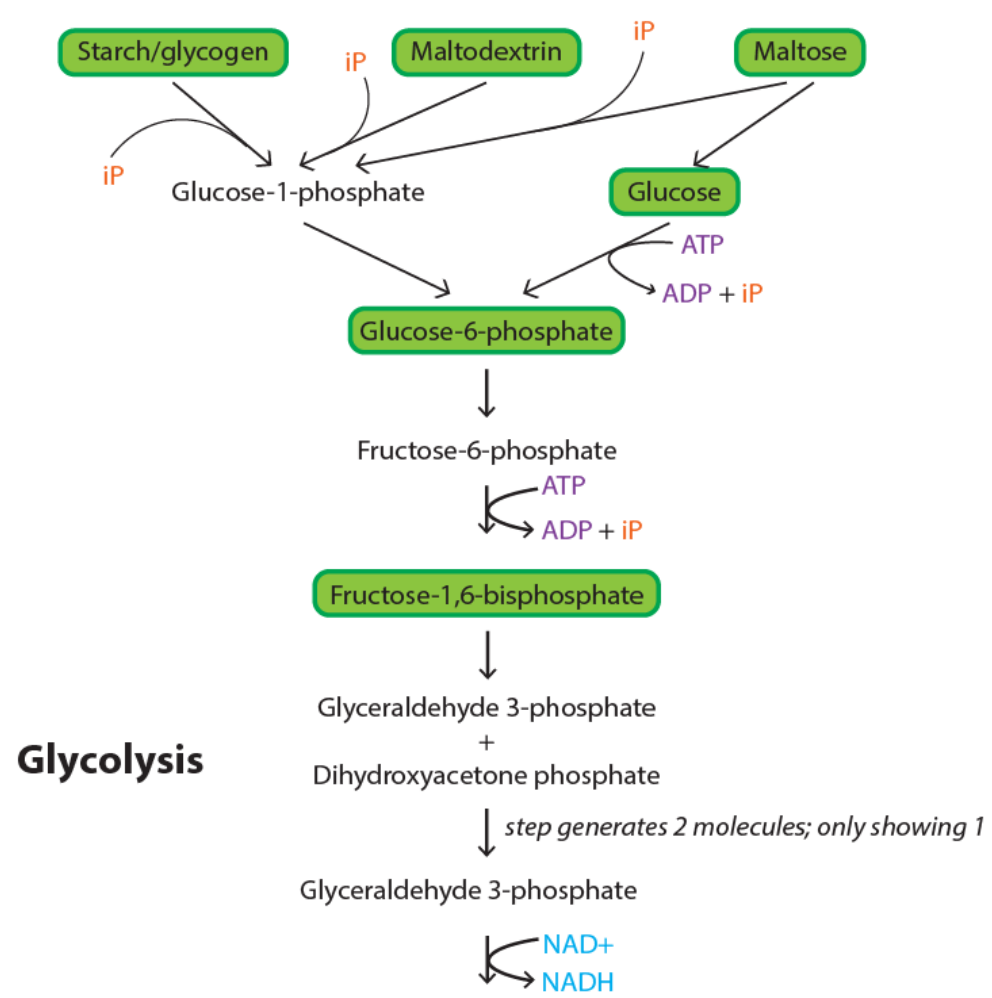

1,3-Bisphosphoglycerate

$$
\varlimsup_{\text {ADP }}^{\text {ATP }}
$$

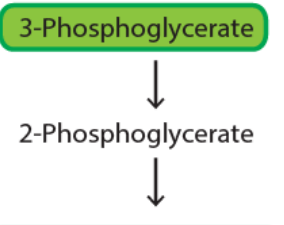

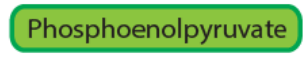

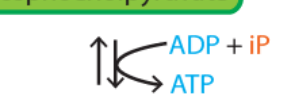

TCA Cycle

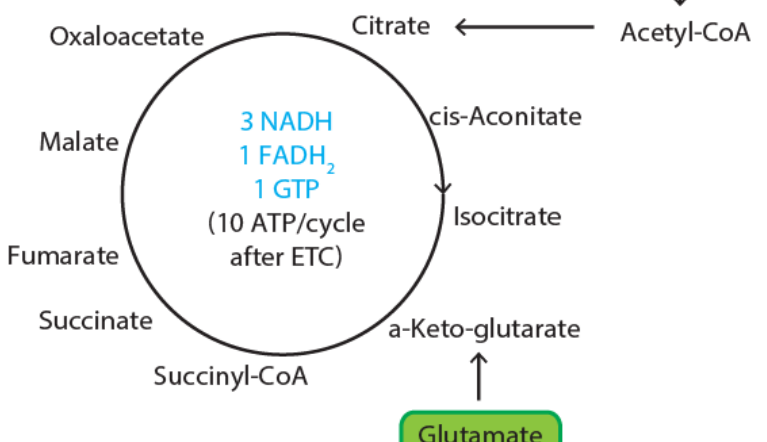

Glutamate

\section{Fermentation}
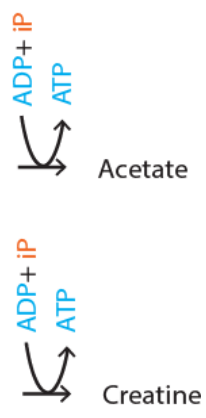

Figure 4. Simplified map of E. coli cell-free metabolism. Map is divided into Glycolysis, TCA Cycle, and Fermentation; areas in green are energy sources that have been explored for cell-free metabolism. 


\section{Single-step (substrate level) phosphorylation}

The earliest iterations of cell-free extracts utilized molecules containing highenergy phosphate bonds as their source of energy (Figure 5). This paradigm remained relatively unchanged for many years. The most popular has been phosphoenolpyruvate (PEP) (Zubay, 1973). While PEP and pyruvate kinase (PK) together produced ATP, Spirin and colleagues hypothesized that acetyl phosphate could provide a cheaper alternative, and demonstrated equivalent signal with acetyl phosphate alone (Ryabova et al., 1995). This was the first evidence substrate-level phosphorylation was relatively independent of high-energy molecule chosen, and endogenous enzymes could be utilized. ${ }^{1}$ Four years later, Yokoyama and colleagues showed a completely exogenous system, creatine phosphate (CP), could also be used in conjunction with enzyme creatine kinase (CK) (Kigawa et al., 1999). CP/CK was tested after finding that PEP had inhibitory effects on cell-free reactions, which would later be attributed to inorganic phosphate accumulation from non-specific phosphatase degradation (D.-M. Kim \& Swartz, 1999). Pyruvate kinase, creatine kinase, and acetate kinase each transfer their high-energy phosphate bonds to ADP to form ATP via substrate-level phosphorylation.
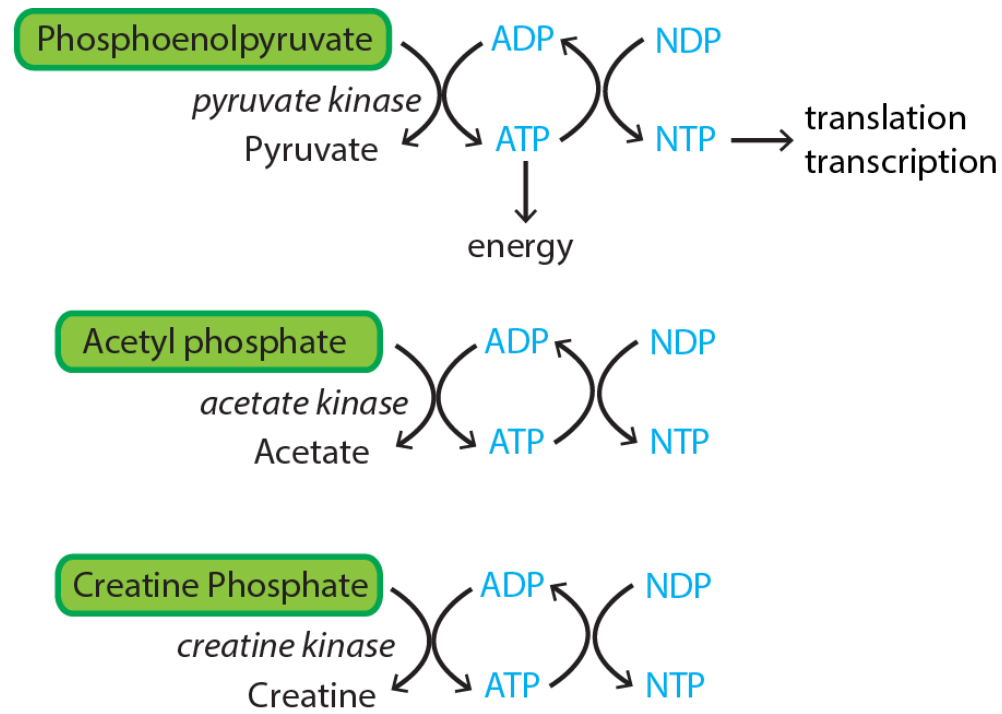

Figure 5. Substrate-level phosphorylation. Shown are three substrate-level phosphorylation modes utilized for cell-free systems: phosphoenolpyruvate/pyruvate kinase, acetyl phosphate/acetate kinase, and creatine phosphate/creatine kinase.

\footnotetext{
${ }^{1}$ It is likely that if PEP was supplied alone, the system would still produce ATP from the endogenous pyruvate kinase present in the extracts.
} 
Although single-step phosphorylation of ATP is simple and effective in energizing cell-free protein synthesis, the use of PEP, CP, and AP has a number of drawbacks. The utility of high-energy phosphate molecules as energy donors is limited by their susceptibility to nonspecific attack by endogenous phosphatases (D.-M. Kim \& Swartz, 1999; 2000b). The result is very transient expression as the energy molecules are quickly degraded. $70 \%$ of PEP was degraded into pyruvate and inorganic phosphate after a 30-minute incubation in $\mathrm{S} 30$ extract in the absence of DNA, indicating the presence of an unproductive sink for the supplied energy source (D.-M. Kim \& Swartz, 1999). Protein yield is further limited by the accumulation of high concentrations of inorganic phosphate in solution resulting from the unproductive cleavage of the highenergy phosphate bonds. Reactions quickly terminate when phosphate concentrations reach 40-50 $\mathrm{mM}$ as a result of chelation of magnesium (T.-W. Kim, Oh, et al., 2007b), which is essential to biologically activating ATP and the function of essential enzymes (D.-M. Kim \& Swartz, 1999). Altogether, this results in reactions not exceeding 1-2 hours in duration. To some extent, replenishing magnesium and the energy source in the reaction has been demonstrated to extend the duration of protein synthesis but such an approach rules out simple batch-mode reactions (D.-M. Kim \& Swartz, 2000b). Another solution explored addition of inorganic phosphate and glucose to the growth medium in which the cells are grown, which limited phosphatase activity in extracts by suppressing expression of phosphatases during growth (R. G. Kim \& Choi, 2000).

\section{Multi-step pathway phosphorylation}

A number of different systems from 1999 onwards were developed to address the weaknesses inherent in systems dependent on high-energy phosphate-bonded compounds. These strategies relied on utilizing multi-step enzymatic pathways in order to more efficiently harness the energy of the high-energy phosphate compounds. By utilizing multi-step pathways, substrates would be less prone to phosphatase attack and a spike in inorganic phosphate concentrations. In addition, ATP generation could be extended over the course of the reaction. The first multi-step system generated acetyl phosphate through the addition of pyruvate and pyruvate oxidase in the presence of 
thiamine pyrophosphate (TPP) and flavin adenine dinucleotide (FAD) (D.-M. Kim \& Swartz, 1999). Substrate-level phosphorylation of acetyl phosphate produces ATP by endogenous acetate kinase. This method is more resistant to phosphatase activity as a lower, sustained concentration of acetyl phosphate is lower relative to the $\mathrm{K}_{\mathrm{m}}$ of the phosphatases. Importantly, the use of an un-phosphorylated substrate serves as an inorganic phosphate sink, thereby preventing phosphate buildup by coupling the activity of pyruvate oxidase to the inorganic phosphate produced by acetyl kinase.

In 2001, the PANOx system (PEP, amino acids, NAD+, oxalic acid) debuted as a highly rationally-engineered multi-step pathway phosphorylation system (D.-M. Kim \& Swartz, 2001) (Figure 6). PANOx employs multiple enzymatic steps to more efficiently harness the energy of high-energy phosphorylated molecules. This system utilizes PEP as the main source of energy but benefits from substrate-level phosphorylation at two points: the conversation of PEP to pyruvate, and the conversion of acetyl phosphate to acetate. The latter conversion is enabled by the addition of NAD+ and CoA, which drive the conversation of pyruvate to acetate. Addition of oxalic acid prevents the nonproductive reverse reaction of pyruvate to PEP by inhibiting the activity of PEP synthase (D.-M. Kim \& Swartz, 2000a), thereby driving flux forward. Finally, amino acids were supplemented to replace degradation of arginine, serine, tryptophan, and cysteine (Michel-Reydellet et al., 2004). The second generation of this system, PANOx-SP adapted the PANOx environment to look more like the cell by replacing polyethylene glycol with spermidine and putracine (the SP of PANOx-SP), and removing HEPES buffer (Jewett \& Swartz, 2004a). These changes were made to encourage metabolism of pyruvate, as pyruvate alone provided only $20 \%$ of the signal of PEP. The PANOx, PANOx-SP, and variants thereof are still widely in use as energy regeneration methods, both in academic settings (T Michaele Holland \& Bundy, 2012; Hong et al., 2014; Kwon \& Jewett, 2015) and in commercial settings (Roche, now Biotechrabbit RTS-100). 


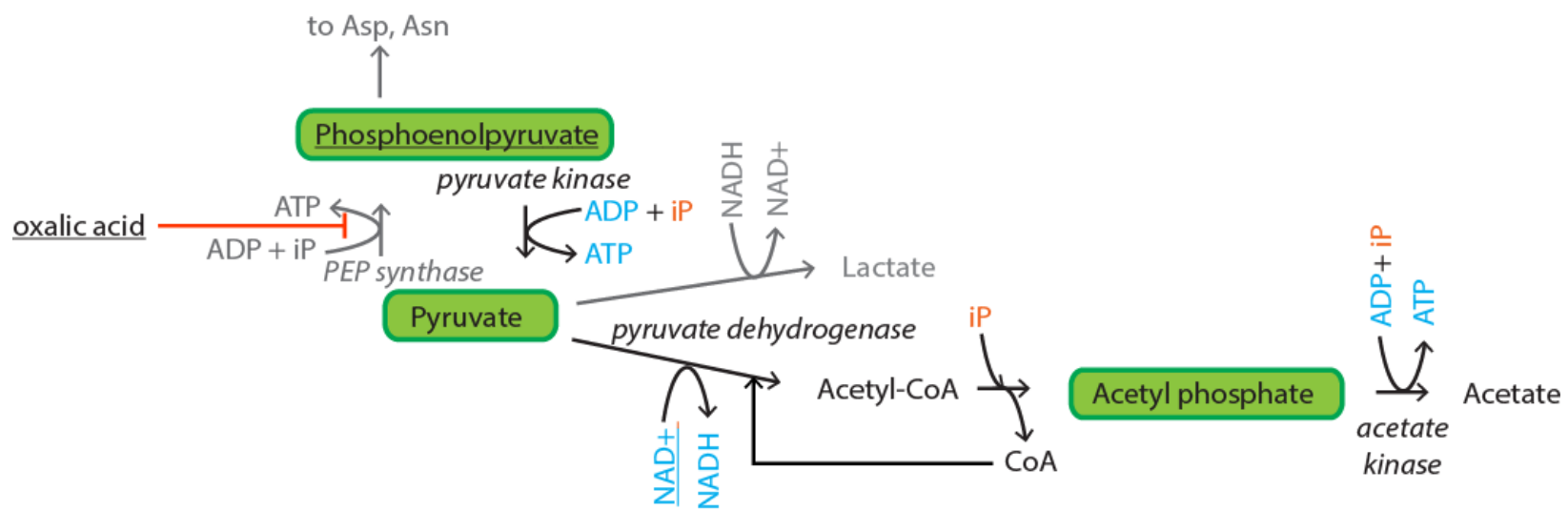

Figure 6. PANOx energy regeneration system. Underlined are PANOx additives (amino acids not shown). In grey are non-productive pathways. In italics are enzymes. ATP is generated from conversion of PEP to pyruvate via pyruvate kinase, and converstion of acetyl phosphate to acetate via acetate kinase. Figure adapted from (Jim Swartz, 2006)

Also in 2001, glucose-6-phosphate (G6P) was found as sufficient to energize cell-free reactions (D.-M. Kim \& Swartz, 2001). This finding was particularly notable, as G6P is 9 steps removed from pyruvate in the glycolytic pathway. At worst case, G6P required conversion to fructose-1,6-biphosphate (F1,6-BP) before substrate-level phosphorylation; at best case, the catabolic machinery for glycolysis remained intact in cell-free extracts. Logically, it follows that any of the intermediates in the glycolytic pathway can be utilized as the starting substrate for ATP regeneration. Following this line of reasoning, 3-phosphoglycerate (3-PGA), a glycolytic intermediate two steps upstream of PEP, was employed as a primary energy source to offer further improvement on the existing ATP regeneration paradigm. By co-opting endogenous enzymes to generate PEP in situ from 3-PGA, Chatterjee and colleagues were able to extend the duration of protein synthesis well beyond the limit of an analogous system utilizing PEP (Sitaraman et al., 2004). The continuous synthesis of PEP allowed the system to evade the phosphatase activity that hampered ATP regeneration by maintaining PEP at low enough concentrations to avoid premature degradation. The 3PGA system would form the basis of prototyping extracts from Noireaux, Murray, and colleagues (Shin \& Noireaux, 2010; Sun et al., 2013). Similarly, F1,6-BP, which is further upstream than 3-PGA, was demonstrated to outstrip 3-PGA as an energy donor 
as theoretically one molecule of FBP would yield more ATP than intermediates downstream (T.-W. Kim, Keum, et al., 2007a).

The glycolytic pathway, in its entirety, has also been leveraged for the cheap and efficient replenishment of ATP. In such a situation, glucose, the cost of which is negligible relative to most other energy sources, can serve as an economical and efficient substrate for energizing protein expression. In contrast to traditional substratelevel phosphorylation reactions that yield only one mole of ATP per mole of costly energy molecule, one mole of glucose can yield 2 or 3 moles of ATP, respectively. A landmark moment was the usage of glucose, notable as a cheap substrate, for energizing cell-free systems in parallel with NMPs (vs. NTPs) (Calhoun \& Swartz, 2005c). While effective, glucose metabolism was found to decrease the $\mathrm{pH}$ of the reaction below the physiological range as a result of organic acid production (Calhoun \& Swartz, 2005b), thereby requiring extensive buffering. Reactions utilizing glucose required the addition of inorganic phosphate in addition to $\mathrm{pH}$ buffering to express on par with G6P. One approach coupled glucose metabolism with creatine phosphate and creatine kinase in a complementary energy regeneration system (T.-W. Kim, Oh, et al., 2007b). The normally inhibitory inorganic phosphate from creatine phosphate metabolism served as the phosphate source necessary to activate glucose metabolism. Although the amount of protein yielded by this combination of resources was high, the return to creatine phosphate offset this advantage with a much higher cost to yield ratio. Another iteration refined the parameters for glucose utilization and dramatically extended reaction duration and productivity, resulting in a six-hour reaction yielding 1.8 $\mathrm{mg} / \mathrm{mL}$ of protein (T.-W. Kim, Kim, Oh, \& Kim, 2008). This was accomplished by growing the cells in the presence of glucose and phosphate, further fortifying the $\mathrm{pH}$ buffering capacity, and utilizing the $\mathbf{S} 12$ extract preparation method to preserve cofactors.

Recently, cell-free systems have been engineered to use complex sugars in order to prevent $\mathrm{pH}$ issues, maintain cost advantage, and allow for long-lasting energy release. Wang and Zhang (YHP) in 2009 demonstrated that maltodextrin, in combination with supplemental maltodextrin phosphorylase and phosphoglucomutase, could effectively energize cell-free reactions at very low cost (Y. Wang \& Zhang, 2009). 
This strategy integrates phosphorolysis to serve as an inorganic phosphate sink and glycolysis in addition to the PANOx pathway to generate ATP. Each glucose equivalent in maltodextrin can produce one more net ATP relative to glucose by consuming inorganic phosphate rather than ATP in the formation of G6P. Maltodextrin resulted in less $\mathrm{pH}$ perturbations (relative to glucose, PEP, and G6P in analogous systems), and in more homeostatic and stable reaction conditions. Further refinement of the polysaccharide approach utilizing starch and glycogen demonstrated that protein synthesis could continue for 12 hours in a simple batch mode, yielding $1.7 \mathrm{mg} / \mathrm{mL}$ of protein without addition of exogenous enzymes (H.-C. Kim, Kim, \& Kim, 2011). Kim et al. also demonstrated the maintenance of a steady supply of ATP without drastic alteration of $\mathrm{pH}$ which they postulated might explain the improved solubility of synthesized protein. Quantification of the ATP and starch levels after cessation of transcription at 12 hours showed that only $20 \%$ of the starch had been consumed and ATP concentrations were still constant, implying that ATP supply was not the limiting factor. In an effort to improve upon the system by introducing a gradually released phosphate reservoir, bypassing the presence of potentially inhibitory amounts of inorganic phosphate, hexametaphosphate was recently utilized in place of potassium phosphate (Caschera \& Noireaux, 2015). An approach combining the strengths of the 3PGA system with maltose, a disaccharide acting as an inorganic phosphate sink and secondary energy source was also pursued (Caschera \& Noireaux, 2013).

\section{Oxidative Phosphorylation}

The Cytomim system was originally produced to metabolize (cheaper) pyruvate in lieu of (more expensive) PEP, with the working hypothesis that conditions more representative of the cytoplasm would be necessary for pyruvate utilization (Jewett \& Swartz, 2004b; 2004a). Interestingly, however, Jewett and Swartz discovered that ATP generation and protein synthesis continued beyond the depletion of pyruvate, the presumed energy substrate. On follow-up, the depletion of glutamate and formation of TCA cycle intermediates was observed, demonstrating that glutamate alone could serve as a stand-alone energy substrate (Jewett et al., 2008). This process was found to be heavily oxygen-dependent, thereby confirming that oxidative phosphorylation could be 
activated in cell-free extracts. Biochemical inhibitors of the electron transport chain also significantly reduced the protein yielded by the cell-free system. This represents a substantial shift in thinking, as the TCA cycle as well as the electron transport chain are necessary. It was theorized that lysis methods causing high shear rates (eg. highpressure homogenization) allows inverted membrane vesicles (IMVs) upon which oxidative phosphorylation can occur.

\section{Energy Regeneration in the context of Synthetic Biology}

While there has been extensive innovation in energy regeneration in cell-free systems, less clear are the conditions that are necessary to enable synthetic biology applications to function, such as the rapid prototyping of circuits (Garamella et al., 2016; Sun et al., 2014; Takahashi et al., 2015) and of pathways (Karim \& Jewett, 2016; Wu, Culler, Khandurina, Van Dien, \& Murray, 2015). For circuit prototyping specifically, one can assume that interactions such as protein-binding strength to operators, or weak $\mathrm{K}_{\mathrm{m}}$ binding events, are more critical than pure protein expression. In addition, native polymerases are favored over T7 polymerase to better emulate cellular conditions (Shin \& Noireaux, 2010). With a goal of prototyping to match cellular function and implement complexity (versus pure protein production), it is likely that re-evaluation of existing approaches will be necessary to support this new application. To date, two protocols have been used for circuit prototyping: (1) a protocol utilizing bead-beating and 3-PGA energy regeneration (Sun et al., 2013), and (2) a protocol mixing bead-beating or French-press preparation and 3-PGA with maltodexrin and/or maltose (Garamella et al., 2016). In addition, the protocol of (Sun et al., 2013) has been used for prototyping pathways for 1,4-BDO (Wu et al., 2015) and violacein (Nguyen, Wu, Guo, \& Murray, 2015), as well as a modified PANOx-SP run off of T7 RNA polymerase for n-butanol (Karim \& Jewett, 2016). However, there has been no published work on engineering of the cell-free protocol to specifically support circuit prototyping.

While we now know that cell-free systems contain large amounts of intact metabolism, there is also a need to apply -omics technologies (genomics, proteomics, metabolomics, transcriptomics, glycomics) to better understand the cell-free "black-box." 
Since the dense period of discovery from 1999 - 2011, there has been a lack of published work seeking to understand the extent to which central metabolism can be activated and manipulated. This is particularly compelling with the new tools available since the bulk of discovery was conducted, including RNAseq (Mortazavi, Williams, McCue, Schaeffer, \& Wold, 2008), high-throughput gene synthesis and assembly (Kosuri et al., 2010), and high-throughput gene sequencing (Shendure, Mitra, Varma, \& Church, 2004). It is also increasingly evident that cell-free systems are not uniform, standard "collections" of lysates, but rather complex compositions that are affected by the multiple variables of preparation and energizing. These complex compositions may require standardization of preparation, or individual analysis per batch to understand variability that result extract-to-extract (Takahashi et al., 2014; 2015). Attempts by Panke and colleagues to conduct real-time analysis on lysates is a start at understanding this complexity (Bujara, Schümperli, Pellaux, Heinemann, \& Panke, 2011).

\section{ACKNOLEDGEMENTS}

The authors declare a conflict of interest: ACC, RMM, ZSS hold ownership in Synvitrobio, Inc. The work presented here was funded off of a DARPA SBIR to Synvitrobio, Inc. (ACC, ZSS), contract No: W911NF-16-P-0003, and a Caltech Grubstake Grant (ACC, RMM, ZSS). The views and conclusions contained in this document are those of the authors and should not be interpreted as representing officially policies, either expressly or implied, of the Defense Advanced Research Projects Agency or the U.S. Government.

\section{REFERENCES}

Airen, I. O. (2011). Genome-wide functional genomic analysis for physiological investigation and improvement of cell-free protein synthesis, 1-529. Retrieved from http://purl.stanford.edu/db775qj4850

Bosdriesz, E., Molenaar, D., Teusink, B., \& Bruggeman, F. J. (2015). How fast-growing bacteria robustly tune their ribosome concentration to approximate growth-rate maximization. FEBS Journal, 282(10), 2029-2044. 
http://doi.org/10.1111/febs.13258

Bujara, M., Schümperli, M., Pellaux, R., Heinemann, M., \& Panke, S. (2011).

Optimization of a blueprint for in vitro glycolysis by metabolic real-time analysis. Nat Chem Biol, 7(5), 271-277. http://doi.org/10.1038/nchembio.541

Calhoun, K. A., \& Swartz, J. R. (2005a). An Economical Method for Cell-Free Protein Synthesis using Glucose and Nucleoside Monophosphates. Biotechnol Prog, 21(4), 1146-1153. http://doi.org/10.1021/bp050052y

Calhoun, K. A., \& Swartz, J. R. (2005b). Energizing cell-free protein synthesis with glucose metabolism. Biotechnol Bioeng, 90(5), 606-613. http://doi.org/10.1002/bit.20449

Calhoun, K. A., \& Swartz, J. R. (2005c). Energizing cell-free protein synthesis with glucose metabolism. Biotechnol Bioeng, 90(5), 606-613.

http://doi.org/10.1002/bit.20449

Calhoun, K. A., \& Swartz, J. R. (2006). Total amino acid stabilization during cell-free protein synthesis reactions. J Biotechnol, 123(2), 193-203. http://doi.org/10.1016/j.jbiotec.2005.11.011

Carlson, E. D., Gan, R., Hodgman, C. E., \& Jewett, M. C. (2012). Cell-free protein synthesis: Applications come of age. Biotechnology Advances, 30(5), 1185-1194. http://doi.org/10.1016/j.biotechadv.2011.09.016

Caschera, F., \& Noireaux, V. (2013). Synthesis of 2.3\&nbsp;mg/ml of protein with an all Escherichia coli cell-free transcription-translation system. Biochimie, 99, 1-7. http://doi.org/10.1016/j.biochi.2013.11.025

Caschera, F., \& Noireaux, V. (2014). Synthesis of $2.3 \mathrm{mg} / \mathrm{ml}$ of protein with an all Escherichia coli cell-free transcription-translation system. Biochimie, 99, 162-168. http://doi.org/10.1016/j.biochi.2013.11.025

Caschera, F., \& Noireaux, V. (2015). A cost-effective polyphosphate-based metabolism fuels an all E. coli cell-free expression system. Metab Eng, 27, 29-37. http://doi.org/10.1016/j.ymben.2014.10.007

Chisti, Y., \& Moo-Young, M. (1986). Disruption of microbial cells for intracellular products. Enzyme and Microbial Technology, 8(4), 194-204. http://doi.org/10.1016/0141-0229(86)90087-6

de los Santos, E. L. C., Meyerowitz, J. T., Mayo, S. L., \& Murray, R. M. (2015). Engineering Transcriptional Regulator Effector Specificity Using Computational Design and In VitroRapid Prototyping: Developing a Vanillin Sensor. ACS Synth Biol, 150819141300002. http://doi.org/10.1021/acssynbio.5b00090

Ezure, T., Suzuki, T., Higashide, S., Shintani, E., Endo, K., Kobayashi, S. I., et al. (2006). Cell-Free Protein Synthesis System Prepared from Insect Cells by FreezeThawing. Biotechnol Prog, 22(6), 1570-1577. http://doi.org/10.1021/bp060110v

Fischer, S. (2016). Cell Break: How Cell-Free Biology Is Finally Putting the Engineering Back in Bioengineering. IEEE Pulse. http://doi.org/10.1109/MPUL.2016.2514881

Garamella, J., Marshall, R., Rustad, M., \& Noireaux, V. (2016). The all E. coli TX-TL Toolbox 2.0: a platform for cell-free synthetic biology. ACS Synthetic ..., acssynbio.5b00296. http://doi.org/10.1021/acssynbio.5b00296

Gesteland, R. F. (1966). Isolation and characterization of ribonuclease I mutants of Escherichia coli. J Mol Biol, 16(1), 67-84. http://doi.org/10.1016/S00222836(66)80263-2 
Hodgman, C. E., \& Jewett, M. C. (2012). Cell-free synthetic biology: Thinking outside the cell. Metab Eng, 14(3), 261-269. http://doi.org/10.1016/j.ymben.2011.09.002

Holland, T Michaele, \& Bundy, B. C. (2012). Streamlined extract preparation for Escherichia coli-based cell-free protein synthesis by sonication or bead vortex mixing. Biotechniques.

Hong, S. H., Kwon, Y.-C., Martin, R. W., Soye, Des, B. J., de Paz, A. M., Swonger, K. N., et al. (2015). Improving Cell-Free Protein Synthesis through Genome Engineering of Escherichia coli Lacking Release Factor 1. ChemBioChem, 16(5), 844-853. http://doi.org/10.1002/cbic.201402708

Hong, S. H., Ntai, I., Haimovich, A. D., Kelleher, N. L., Isaacs, F. J., \& Jewett, M. C. (2014). Cell-free Protein Synthesis from a Release Factor 1 Deficient Escherichia coli Activates Efficient and Multiple Site-specific Nonstandard Amino Acid Incorporation. ACS Synthetic ..., 3(6), 398-409. http://doi.org/10.1021/sb400140t Jermutus, L., Ryabova, L. A., \& Plückthun, A. (1998). Recent advances in producing and selecting functional proteins by using cell-free translation. Curr Opin Biotechnol, 9(5), 534-548. http://doi.org/10.1016/S0958-1669(98)80042-6

Jewett, M. C., \& Swartz, J. R. (2004a). Mimicking the Escherichia coli cytoplasmic environment activates long-lived and efficient cell-free protein synthesis. Biotechnol Bioeng, 86(1), 19-26. http://doi.org/10.1002/bit.20026

Jewett, M. C., \& Swartz, J. R. (2004b). Substrate replenishment extends protein synthesis with an in vitro translation system designed to mimic the cytoplasm. Biotechnol Bioeng, 87(4), 465-471. http://doi.org/10.1002/bit.20139

Jewett, M. C., Calhoun, K. A., Voloshin, A., Wuu, J. J., \& Swartz, J. R. (2008). An integrated cell-free metabolic platform for protein production and synthetic biology., 4, 220. http://doi.org/10.1038/msb.2008.57

Johnson, B. H., \& Hecht, M. H. (1994). Cells by Repeated Cycles of Freezing and Thawing. Bio/Technology.

Kang, S. H., Kim, D.-M., Kim, H. J., Jun, S. Y., Lee, K. Y., \& Kim, H. J. (2005). Cell-Free Production of Aggregation-Prone Proteins in Soluble and Active Forms. Biotechnol Prog, 21(5), 1412-1419. http://doi.org/10.1021/bp050087y

Karim, A. S., \& Jewett, M. C. (2016). A cell-free framework for rapid biosynthetic pathway prototyping and enzyme discovery. Metab Eng. http://doi.org/10.1016/j.ymben.2016.03.002

Kigawa, T., Yabuki, T., Matsuda, N., Matsuda, T., Nakajima, R., Tanaka, A., \& Yokoyama, S. (2004a). Preparation of Escherichia coli cell extract for highly productive cell-free protein expression. J Struct Funct Genomics, 5(1-2), 63-68. http://doi.org/10.1023/B:JSFG.0000029204.57846.7d

Kigawa, T., Yabuki, T., Matsuda, N., Matsuda, T., Nakajima, R., Tanaka, A., \& Yokoyama, S. (2004b). Preparation of Escherichia coli cell extract for highly productive cell-free protein expression. J Struct Funct Genomics, 5(1-2), 63-68. http://doi.org/10.1023/B:JSFG.0000029204.57846.7d

Kigawa, T., Yabuki, T., Yoshida, Y., Tsutsui, M., \& Ito, Y. (1999). Cell-free production and stable-isotope labeling of milligram quantities of proteins - Kigawa - 1999 FEBS Letters - Wiley Online Library. Febs .... http://doi.org/10.1016/S00145793(98)01620-2/pdf

Kim A Woodrow, Isoken O Airen, A., \& Swartz, J. R. (2006). Rapid Expression of 
Functional Genomic Libraries. J Proteome Res, 5(12), 3288-3300. http://doi.org/10.1021/pr050459y

Kim, D. M., \& Choi, C. Y. (1996). A Semicontinuous Prokaryotic Coupled

Transcription/Translation System Using a Dialysis Membrane - Kim - 1996 -

Biotechnology Progress - Wiley Online Library. Biotechnol Prog. http://doi.org/10.1021/bp960052l/pdf

Kim, D.-M., \& Swartz, J. R. (1999). Prolonging cell-free protein synthesis with a novel ATP regeneration system. Biotechnol Bioeng, 66(3), 180-188.

http://doi.org/10.1002/(SICI)1097-0290(1999)66:3<180::AID-BIT6>3.0.CO;2-S

Kim, D.-M., \& Swartz, J. R. (2000a). Oxalate improves protein synthesis by enhancing ATP supply in a cell-free system derived from Escherichia coli. Biotechnology Letters, 22(19), 1537-1542. http://doi.org/10.1023/A:1005624811710

Kim, D.-M., \& Swartz, J. R. (2000b). Prolonging Cell-Free Protein Synthesis by Selective Reagent Additions. Biotechnol Prog, 16(3), 385-390. http://doi.org/10.1021/bp000031y

Kim, D.-M., \& Swartz, J. R. (2001). Regeneration of adenosine triphosphate from glycolytic intermediates for cell-free protein synthesis. Biotechnol Bioeng, 74(4), 309-316. http://doi.org/10.1002/bit.1121

Kim, D.-M., Kigawa, T., Choi, C.-Y., \& Yokoyama, S. (1996). A Highly Efficient Cell-Free Protein Synthesis System from Escherichia coli. European Journal of Biochemistry, 239(3), 881-886. http://doi.org/10.1111/j.1432-1033.1996.0881u.x

Kim, H.-C., Kim, T.-W., \& Kim, D.-M. (2011). Prolonged production of proteins in a cellfree protein synthesis system using polymeric carbohydrates as an energy source. Process Biochemistry, 46(6), 1366-1369. http://doi.org/10.1016/j.procbio.2011.03.008

Kim, R. G., \& Choi, C. Y. (2000). Expression-independent consumption of substrates in cell-free expression system from Escherichia coli. J Biotechnol, 84(1), 27-32. http://doi.org/10.1016/S0168-1656(00)00326-6

Kim, T. W., Keum, J. W., Oh, I. S., Choi, C. Y., Park, C. G., \& Kim, D. M. (2006). Simple procedures for the construction of a robust and cost-effective cell-free protein synthesis system. J Biotechnol, 126(4), 554-561. http://doi.org/10.1016/j.jbiotec.2006.05.014

Kim, T.-W., Keum, J.-W., Oh, I.-S., Choi, C.-Y., Kim, H.-C., \& Kim, D.-M. (2007a). An economical and highly productive cell-free protein synthesis system utilizing fructose-1,6-bisphosphate as an energy source. J Biotechnol, 130(4), 389-393. http://doi.org/10.1016/j.jbiotec.2007.05.002

Kim, T.-W., Kim, H.-C., Oh, I.-S., \& Kim, D.-M. (2008). A highly efficient and economical cell-free protein synthesis system using the S12 extract of Escherichia coli. Biotechnology and Bioprocess Engineering, 13(4), 464-469. http://doi.org/10.1007/s12257-008-0139-8

Kim, T.-W., Oh, I.-S., Keum, J.-W., Kwon, Y.-C., Byun, J. Y., Lee, K. H., et al. (2007b). Prolonged cell-free protein synthesis using dual energy sources: Combined use of creatine phosphate and glucose for the efficient supply of ATP and retarded accumulation of phosphate. Biotechnol Bioeng, 97(6), 1510-1515. http://doi.org/10.1002/bit.21337

Knapp, K. G., \& Swartz, J. R. (2007). Evidence for an additional disulfide reduction 
pathway in Escherichia coli. Journal of Bioscience and Bioengineering, 103(4), 373376. http://doi.org/10.1263/jbb.103.373

Knapp, K. G., Goerke, A. R., \& Swartz, J. R. (2007). Cell-free synthesis of proteins that require disulfide bonds using glucose as an energy source. Biotechnol Bioeng, 97(4), 901-908. http://doi.org/10.1002/bit.21296

Kosuri, S., Eroshenko, N., LeProust, E. M., Super, M., Way, J., Li, J. B., \& Church, G. M. (2010). Scalable gene synthesis by selective amplification of DNA pools from high-fidelity microchips. Nature Biotechnology, 28(12), 1295-1299. http://doi.org/10.1038/nbt.1716

Krieg, P. A., \& Melton, D. A. (1987). [25] In vitro RNA synthesis with SP6 RNA polymerase. In Recombinant DNA Part F (Vol. 155, pp. 397-415). Elsevier. http://doi.org/10.1016/0076-6879(87)55027-3

Kuchenreuther, J. M., Shiigi, S. A., \& Swartz, J. R. (2014). Cell-Free Synthesis of the HCluster: A Model for the In Vitro Assembly of Metalloprotein Metal Centers. In Molecular Methods for Evolutionary Genetics (Vol. 1122, pp. 49-72). Totowa, NJ: Humana Press. http://doi.org/10.1007/978-1-62703-794-5_5

Kwon, Y.-C., \& Jewett, M. C. (2015). High-throughput preparation methods of crude extract for robust cell-free protein synthesis. Scientific Reports, 5, 8663. http://doi.org/10.1038/srep08663

Kwon, Y.-C., Oh, I.-S., Lee, N., Lee, K. H., Yoon, Y. J., Lee, E. Y., et al. (2013). Integrating cell-free biosyntheses of heme prosthetic group and apoenzyme for the synthesis of functional P450 monooxygenase. Biotechnol Bioeng, 110(4), 11931200. http://doi.org/10.1002/bit.24785

Liu, D. V., Zawada, J. F., \& Swartz, J. R. (2005). Streamlining Escherichia Coli S30 Extract Preparation for Economical Cell-Free Protein Synthesis. Biotechnol Prog, 21(2), 460-465. http://doi.org/10.1021/bp049789y

Mandel, M., \& Higa, A. (1970). Calcium-dependent bacteriophage DNA infection. J Mol Biol, 53(1), 159-162. http://doi.org/10.1016/0022-2836(70)90051-3

Martemyanov, K. A., Shirokov, V. A., Kurnasov, O. V., Gudkov, A. T., \& Spirin, A. S. (2001). Cell-Free Production of Biologically Active Polypeptides: Application to the Synthesis of Antibacterial Peptide Cecropin. Protein Expression and Purification, 21(3), 456-461. http://doi.org/10.1006/prep.2001.1400

Mehta, K. K., Evitt, N. H., \& Swartz, J. R. (2015). Chemical lysis of cyanobacteria. Journal of Biological ....

Michel-Reydellet, N., Calhoun, K., \& Swartz, J. (2004). Amino acid stabilization for cellfree protein synthesis by modification of the Escherichia coli genome. Metab Eng, 6(3), 197-203. http://doi.org/10.1016/j.ymben.2004.01.003

Michel-Reydellet, N., Woodrow, K., \& Swartz, J. (2005). Increasing PCR fragment stability and protein yields in a cell-free system with genetically modified Escherichia coli extracts. Journal of Molecular Microbiology and Biotechnology, 9(1), 26-34. http://doi.org/10.1159/000088143

Miller, D. N., Bryant, J. E., Madsen, E. L., \& Ghiorse, W. C. (1999). Evaluation and Optimization of DNA Extraction and Purification Procedures for Soil and Sediment Samples. Applied and Environmental Microbiology, 65(11), 4715-4724.

Mortazavi, A., Williams, B. A., McCue, K., Schaeffer, L., \& Wold, B. (2008). Mapping and quantifying mammalian transcriptomes by RNA-Seq. Nat Methods, 5(7), 621- 
628. http://doi.org/10.1038/nmeth.1226

Nguyen, P. H. B., Wu, Y., Guo, S., \& Murray, R. M. (2015). Design Space Exploration of the Violacein Pathway in Escherichia coli Based Transcription Translation Cell-Free System (TX-TL). bioRxiv, 027656. http://doi.org/10.1101/027656

Niederholtmeyer, H., Sun, Z., Hori, Y., \& Yeung, E. (2015). Rapid cell-free forward engineering of novel genetic ring oscillators. eLife. http://doi.org/10.7554/eLife.09771.001

Nirenberg, M. W. (1963). [3] Cell-free protein synthesis directed by messenger RNA (Vol. 6, pp. 17-23). Elsevier. http://doi.org/10.1016/0076-6879(63)06142-5

Nirenberg, M. W., \& Matthaei, J. H. (1961). The dependence of cell-free protein synthesis in E. coli upon naturally occurring or synthetic polyribonucleotides. Proceedings of the National Academy of Sciences of the United States of America, 47, 1588-1602.

Noireaux, V., Bar-Ziv, R., \& Libchaber, A. (2003). Principles of cell-free genetic circuit assembly. Proceedings of the National Academy of Sciences of the United States of America, 100(22), 12672-12677. http://doi.org/10.1073/pnas.2135496100

Pedersen, A., Hellberg, K., Enberg, J., \& Karlsson, B. G. (2011). Rational improvement of cell-free protein synthesis. New Biotechnology, 28(3), 218-224. http://doi.org/10.1016/j.nbt.2010.06.015

Rollin, J. A., Martin del Campo, J., Myung, S., Sun, F., You, C., Bakovic, A., et al. (2015). High-yield hydrogen production from biomass by in vitro metabolic engineering: Mixed sugars coutilization and kinetic modeling. Proc Natl Acad Sci $U$ $S$ A, 112(16), 4964-4969. http://doi.org/10.1073/pnas.1417719112

Ron, E. Z., Kohler, R. E., \& Davis, B. D. (1966). Polysomes Extracted from Escherichia coli by Freeze-Thaw-Lysozyme Lysis. Science, 153(3740), 1119-1120. http://doi.org/10.1126/science.153.3740.1119

Ryabova, L. A., Desplancqh, D., \& Spirin, A. S. (1997). Functional antibody production using cell-free translation: Effects of protein. Nature.

Ryabova, L. A., Vinokurov, L. M., Shekhovtsova, E. A., Alakhov, Y. B., \& Spirin, A. S. (1995). Acetyl Phosphate as an Energy Source for Bacterial Cell-Free Translation Systems. Anal Biochem, 226(1), 184-186. http://doi.org/10.1006/abio.1995.1208

Salehi, A. S. M., Smith, M. T., Bennett, A. M., Williams, J. B., Pitt, W. G., \& Bundy, B. C. (2016). Cell-free protein synthesis of a cytotoxic cancer therapeutic: Onconase production and a just-add-water cell-free system. Biotechnology Journal, 11(2), 274281. http://doi.org/10.1002/biot.201500237

Schilling, C. (2015). Accelerated Development of Biobased Processes New Developments in Platform Technology (pp. 1-44). Presented at the BASF Science Symposium.

Seki, E., Matsuda, N., Yokoyama, S., \& Kigawa, T. (2008). Cell-free protein synthesis system from Escherichia coli cells cultured at decreased temperatures improves productivity by decreasing DNA template degradation. Anal Biochem, 377(2), 156161. http://doi.org/10.1016/j.ab.2008.03.001

Shendure, J., Mitra, R. D., Varma, C., \& Church, G. M. (2004). Advanced sequencing technologies: methods and goals. Nature Reviews Genetics, 5(5), 335-344. http://doi.org/10.1038/nrg1325

Shimizu, Y., Inoue, A., Tomari, Y., Suzuki, T., Yokogawa, T., Nishikawa, K., \& Ueda, T. 
(2001). Cell-free translation reconstituted with purified components. Nature Biotechnology, 19(8), 751-755. http://doi.org/10.1038/90802

Shin, J., \& Noireaux, V. (2010). Efficient cell-free expression with the endogenous E. Coli RNA polymerase and sigma factor 70. J Biol Eng, 4(1), 8-9.

http://doi.org/10.1186/1754-1611-4-8

Shin, J., \& Noireaux, V. (2012). An E. coliCell-Free Expression Toolbox: Application to Synthetic Gene Circuits and Artificial Cells. ACS Synth Biol, 1(1), 29-41. http://doi.org/10.1021/sb200016s

Shrestha, P., Holland, T. M., \& Bundy, B. C. (2012). Streamlined extract preparation for Escherichia coli-based cell-free protein synthesis by sonication or bead vortex mixing. Biotechniques, 53(3), 163-174. http://doi.org/10.2144/0000113924

Sitaraman, K., Esposito, D., Klarmann, G., Le Grice, S. F., Hartley, J. L., \& Chatterjee, D. K. (2004). A novel cell-free protein synthesis system. J Biotechnol, 110(3), 257263. http://doi.org/10.1016/j.jbiotec.2004.02.014

Smith, H. O., \& Welcox, K. W. (1970). A Restriction enzyme from Hemophilus influenzae: I. Purification and general properties. J Mol Biol, 51(2), 379-391. http://doi.org/10.1016/0022-2836(70)90149-X

Spirin, A. S., \& Swartz, J. R. (2008). Cell-free protein synthesis: methods and protocols. Spirin, A. S., Baranov, V. I., Ryabova, L. A., \& Ovodov, S. Y. (1988a). A continuous cellfree translation system capable of producing polypeptides in high yield. Science.

Spirin, A. S., Baranov, V. I., Ryabova, L. A., Ovodov, S. Y., \& Alakhov, Y. B. (1988b). A continuous cell-free translation system capable of producing polypeptides in high yield. Science, 242(4882), 1162-1164. http://doi.org/10.1126/science.3055301

Stricker, J., Cookson, S., Bennett, M. R., Mather, W. H., Tsimring, L. S., \& Hasty, J. (2008). A fast, robust and tunable synthetic gene oscillator. Nature, 456(7221), 516519. http://doi.org/10.1038/nature07389

Sun, Z. Z., Hayes, C. A., Shin, J., Caschera, F., Murray, R. M., \& Noireaux, V. (2013). Protocols for Implementing an Escherichia Coli Based TX-TL Cell-Free Expression System for Synthetic Biology. Journal of Visualized Experiments, e50762(79), e50762-e50762. http://doi.org/10.3791/50762

Sun, Z. Z., Kim, J., Singhal, V., \& Murray, R. M. (2015). Protein degradation in a TX-TL cell-free expression system using ClpXP protease. bioRxiv, 019695. http://doi.org/10.1101/019695

Sun, Z. Z., Yeung, E., Hayes, C. A., Noireaux, V., \& Murray, R. M. (2014). Linear DNA for Rapid Prototyping of Synthetic Biological Circuits in an Escherichia coliBased TX-TL Cell-Free System. ACS Synth Biol, 3(6), 387-397. http://doi.org/10.1021/sb400131a

Swartz, James R. (2012). Transforming biochemical engineering with cell-free biology. AIChE Journal, 58(1), 5-13. http://doi.org/10.1002/aic.13701

Swartz, Jim. (2006). Developing cell-free biology for industrial applications. Journal of Industrial Microbiology and Biotechnology, 33(7), 476-485. http://doi.org/10.1007/s10295-006-0127-y

Takahashi, M. K., Chappell, J., Hayes, C. A., Sun, Z. Z., Kim, J., Singhal, V., et al. (2014). Rapidly Characterizing the Fast Dynamics of RNA Genetic Circuitry with Cell-Free Transcription-Translation (TX-TL) Systems. ACS Synth Biol, 4(5), 140417124539000-515. http://doi.org/10.1021/sb400206c 
Takahashi, M. K., Hayes, C. A., Chappell, J., Sun, Z. Z., Murray, R. M., Noireaux, V., \& Lucks, J. B. (2015). Characterizing and prototyping genetic networks with cell-free transcription-translation reactions. Methods. http://doi.org/10.1016/j.ymeth.2015.05.020

Thompson, J., \& Chassy, B. M. (1981). Uptake and metabolism of sucrose by Streptococcus lactis. J Bacteriol, 147(2), 543-551.

Wang, H. H., Isaacs, F. J., Carr, P. A., Sun, Z. Z., Xu, G., Forest, C. R., \& Church, G. M. (2009). Programming cells by multiplex genome engineering and accelerated evolution. Nature, 460(7257), 894-898. http://doi.org/10.1038/nature08187

Wang, Y., \& Zhang, Y.-H. P. (2009). Cell-free protein synthesis energized by slowlymetabolized maltodextrin. BMC Biotechnology, 9(1), 58. http://doi.org/10.1186/14726750-9-58

Wang, Y., Huang, W., Sathitsuksanoh, N., Zhu, Z., \& Zhang, Y.-H. P. (2011). Biohydrogenation from Biomass Sugar Mediated by In Vitro Synthetic Enzymatic Pathways. Chemistry \& Biology, 18(3), 372-380. http://doi.org/10.1016/j.chembiol.2010.12.019

Woodrow, K. A., \& Swartz, J. R. (2007). A sequential expression system for highthroughput functional genomic analysis. Proteomics, 7(21), 3870-3879. http://doi.org/10.1002/pmic.200700471

Wu, Y. Y., Culler, S., Khandurina, J., Van Dien, S., \& Murray, R. M. (2015). Prototyping 1,4-butanediol (BDO) biosynthesis pathway in a cell-free transcription-translation (TX-TL) system. bioRxiv (pp. 1-7).

Yamane, T., Ikeda, Y., Nagasaka, T., \& Nakano, H. (2005). Enhanced Cell-Free Protein Synthesis Using a S30 Extract from Escherichia coli Grown Rapidly at $42{ }^{\circ} \mathrm{C}$ in an Amino Acid Enriched Medium. Biotechnol Prog, 21(2), 608-613. http://doi.org/10.1021/bp0400238

Yang, J., Kanter, G., Voloshin, A., Levy, R., \& Swartz, J. R. (2004). Expression of Active Murine Granulocyte-Macrophage Colony-Stimulating Factor in an Escherichia coli Cell-Free System. Biotechnol Prog, 20(6), 1689-1696. http://doi.org/10.1021/bp034350b

Yang, W. C., Patel, K. G., Wong, H. E., \& Swartz, J. R. (2012). Simplifying and streamlining Escherichia coli-based cell-free protein synthesis. Biotechnol Prog, 28(2), 413-420. http://doi.org/10.1002/btpr.1509

Yeates, C., Gillings, M. R., Davison, A. D., Altavilla, N., \& Veal, D. A. (1998). Methods for microbial DNA extraction from soil for PCR amplification. Biological Procedures Online, 1(1), 40-47. http://doi.org/10.1251/bpo6

Yin, G., \& Swartz, J. R. (2004). Enhancing multiple disulfide bonded protein folding in a cell-free system - Yin - 2004 - Biotechnology and Bioengineering - Wiley Online Library. Biotechnol Bioeng. http://doi.org/10.1002/bit.10827/pdf

Yin, G., Garces, E. D., Yang, J., Zhang, J., Tran, C., Steiner, A. R., et al. (2012). Aglycosylated antibodies and antibody fragments produced in a scalable in vitro transcription-translation system. mAbs, 4(2), 217-225. http://doi.org/10.4161/mabs.4.2.19202

Zawada, J. F., Yin, G., Steiner, A. R., \& Yang, J. (2011). Microscale to manufacturing scale-up of cell-free cytokine production-a new approach for shortening protein production development timelines - Zawada - 2011 - Biotechnology and 
Bioengineering - Wiley Online Library. Biotechnology and .... http://doi.org/10.1002/bit.23103/pdf

Zawada, J., \& Swartz, J. (2005). Maintaining rapid growth in moderate-density Escherichia coli fermentations - Zawada - 2005 - Biotechnology and Bioengineering - Wiley Online Library. Biotechnol Bioeng. http://doi.org/10.1002/bit.20369/pdf

Zubay, G. (1973). In-Vitro Synthesis of Protein in Microbial Systems. Annual Review of Genetics, 7(1), 267-287. http://doi.org/10.1146/annurev.ge.07.120173.001411 